\title{
MUSIC GEOGRAPHIES AND ICONIC MUSIC LEGENDS: MAPPING CÉLINE DION'S OUTSTANDING CONTRIBUTION TO MUSIC AND GLOBAL POPULAR MUSIC CULTURE
}

\author{
Ioan-Sebastian JUCU \\ West University of Timişoara, Faculty of Chemistry, Biology, Geography, ROMANIA \\ ioan.jucu@e-uvt.ro
}

DOI: http://doi.org/10.23740/TID120195

\section{ABSTRACT}

Between music geography and iconic music legends, a strong connection has been established in terms of spatial and temporal analysis of popular music and the representation of national identities in the contemporary global cultures of popular music. The existing literature unveils a gap in the analysis of music geography and famous musicians, real global music icons identified with particular cultures. This paper argues that such music legends must be geographically studied to unveil their outstanding contribution to the world music cultures. Against such a background, a geographical approach that takes Canadian singer Céline Dion as a case study is developed. The research aims to analyse Dion's outstanding contribution to global music culture in both spatial and temporal terms. Based on the music industry emergence, the paper focuses on how and why Céline Dion appeared in global music culture and examines her outstanding contribution with specific reference to music cartographies and statistical research. National identity and related cultural issues beyond the music, lyrics, and performances are also addressed. The empirically led study is based on a multi-method approach and makes use of statistical data analysis, GIS methods, biographical inquiry, the analysis of lyrics and visual methodologies, all suggesting that Dion's contribution has greatly influenced the global popular music culture of the last few decades. Although the topics in question cannot be fully discussed within the limits of this paper, it highlights the importance of these issues and calls for further in-depth research to provide a new critical understanding of the intimate connections between popular music, legendary music icons and the recent perspectives in music geographies.

Keywords: music industry, cultural globalisation, diffusion, music scenes, famous artists

\section{INTRODUCTION}

This paper deals with music and geography since these fields are "intimately connected" and a legitimate topic of academic research (Johansson \& Bell, 2009, p. 1; Anderson et al., 2005). Music is "one of the world's defining products" (Florida et al., 2010, p. 787), a singular form of symbolic expression shaping human existence (Lull, 1987), a part of people's lives and human experience. It is a universal cultural norm, an expression of human culture (Johansson \& Bell, 2009; Lashua et al., 2014; Levitin, 2006), and "a means by which cultures defined themselves" (Throsby, 2002, p. 2). Music is an agent in the social and cultural reproduction of space and everyday life (Cohen, 1995) with a key role "in the formation of social life and identity" (Milburn, 2017, p. 3) providing multiple opportunities to gain new understandings in 
geographical analysis based on its continuous development over space and through time (Kearney, 2010; Waterman, 2006). Consequently, music "is by nature geographical" (Hogan, 2007, p. 1). It could be used as a platform for specific topics, arguing the contribution of highprofile musicians and emphasizing the global issues of their music (Kearney, 2009, 2010).

Acknowledged "as perfect models of consumption" (Till, 2010, p. 71), global music legends shape representative spatio-temporal pathways in music consumption and thereby influence the global cultures. A review of the existing literature in the field of geography revealed a gap in terms of scientific inquiry into geography and music, especially examining the living famous artists and their contribution in the global popular music culture. Several studies investigated passed away music icons as Beatles, Elvis Presley and Frank Sinatra (Kruse, 2004, 2005; Fraser \& Brown, 2002; Milburn, 2017; Rodman, 2013). Since musicians' behavior is highly encouraged to be geographically studied (Florida et al., 2010) and geographers have only very rarely investigated major figures and legendary music icons of popular music (see Milburn, 2017, p. 3 ), this paper aims to fill this hiatus. It focuses on music geographies and living music legends and particularly on the global music icons with a geographical study of Céline Dion's outstanding contribution to global music culture and on the worldwide cultural influence of this global fame songstress, a real phenomenon in the global music mainstream (Grenier, 2000,2002 ). Dion is one of the best-selling female artists of all time and an iconic legend in the contemporary global music culture. "After 35 years as a performing and recording artist, Dion has become a legend of popular music, one of the most powerful and moving voices ever heard" being the $6^{\text {th }}$ most admired woman on the planet (Dahlgreen, 2016; Bouvia, 2017). ${ }^{1}$ She is a Canadian singer who has diffused her music from local audiences to the world through domestic music deterritorialisation and cultural globalisation (Brown et al., 2000; Connell \& Gibson, 2004, 2009; Richardson \& Wilkie, 2015).

Living music legends contribute to the spatio-temporal development of local and global music cultures shaping representative pathways in music production and consumption, and in local, national and global identity representation, influencing the world's cultures. Since the diffusion of music in recent decades has expanded through commercial and digital broadcasts, recordings and tours (see Lashua et al., 2014; Shuker, 2016), legendary musicians have removed the cultural borders, with people recognizing their common identities through music (Smith, 1997). Where different boundaries (national, political, cultural, artistic or musical) have maintained for various reasons, music has had the power to penetrate them. Consequently, Dion's music has crossed the globe, sharing the real values of music and culture. This songstress became one of the most important artists in the world, a global living legend promoting the identities of French and English music (see Grenier, 2000).

Thoroughly admired, with a global popularity or sometimes criticized, Dion remains one of the most iconic legends of the global music culture. Since the spatial focus is relevant in the contemporary culture of popular music (Florida \& Jackson, 2010; Milburn, 2017), the overall goal of this research is to advance a geographical analysis of how music has made this singer a global music legend. In addition, the main objective of the study is to map and discuss Dion's musical career through the lens of a geographical approach to provide professional maps using GIS methods and to present a spatio-temporal geographic examination of the outstanding musical contribution of this artist to music and global popular music culture.

${ }^{1}$ See http://www.celinedionforum.com and www.celinedion.com, Accessed September 2017. 


\section{MUSIC GEOGRAPHY AND LEGENDARY MUSIC ICONS: TOWARDS A THEORETICAL BACKGROUND}

The main issues in music geographies were considered in the following theoretical background. In line with different states of the art in music geography recently provided by different scholars as Milburn (2017) and prior by Byklum (1994), Johansson \& Bell (2009), Kearney (2009, 2010), Carney (1987a, 1987b, 1990, 1998a, 1998b), Cohen, (1995), Kong (1995), Leyshon et al. (1998), Revill (2005), all the studies in music geography remain influential for decoding the intimate connections between geography, music and legendary artists. The older studies highlight traditional approaches to music, with cultural hearths and spatial patterns of diffusion, key factors in the geographic analysis of music. The complex patterns of diffusion have been found to engage economic development through the emergence of the commercial music industry, advances in information/communication technology and globalisation. Therefore, local music has expanded into contemporary global music through music legends from various cultural hearths all-across the world, generating certain spaces where famous musicians are strongly internalised by fans, people, audiences and communities. Their delimitation is important, particularly when music legends are involved given the strong relationships between music, place, identity, musical practices and music demand (Leyshon et al., 1998; Lieb, 2018).

Since music is "a mirror of society" (Attali, 1985, p. 4), the interchangeable connections between music, culture and the role of economies in music evolution have been discussed without paying much attention to the famous musicians' contribution in the global music cultures. As music permanently inhabits the geographic space (Hudson, 2006), in the same vein music legends are iconic figures for different communities, with a spatio-temporal involvement from local to global cultures influencing places and identities. This approach stated by Cohen (1995) emphasises the meaning of music as residing in "a cultural form that actively produces geographic discourses and can be used to understand broader social relations and trends, including identity, ethnicity, attachment to place, cultural economies, social activism and politics" (Johansson \& Bell, 2009, p. 2). In light of this argument, scholars have focused on music related to the sense of life, to place and cultural identity, to music scenes and the relationship between local and global. Traditions and cultural diffusion, music cartographies and the analysis of lyrics to decode the geographical meanings of music were also unveiled (see Anderson, 2004; Bennett, 2000; Bennett \& Peterson, 2004; Carney, 1974, 2003; Cohen, 2017; Connell \& Gibson, 2003; Gibson \& Connell, 2004; Hudson, 2006; Finn \& Lukinbeal, 2009; Kong, 1995, 1999; Kruse, 2003, 2005, 2009; Kuhlke, 2009; Pesses, 2009; Romig, 2009; Stokes, 1997; Young, 2002). These studies argue the relevance of music geographies by revealing the ways music artists diffuse their cultural values, which are then internalised by different communities worldwide.

The cultural diffusion has enabled music to be consumed under the umbrella of globalisation (Shuker, 2016) and of new creative industries, because music is an integral part of these industries, one that has rapidly expanded in space and time. It dominates markets and media environments and creates music scenes the world over (see Florida et al., 2010; Throsby, 2002). Globalisation is also the background of the music legends production. Through cultural globalisation, music has been the main contributor to the creation of iconic music performers as products and agents of world music, intensely demanded by a large audience. From 1987, world music has connected the local to the global and the traditional with the modern, thus deterritorialising cultures and spreading music worldwide. Therefore, music broadly expanded (Florida et al., 2010) starting to be largely diffused from the West (Connell \& Gibson, 2004) 
shifting places and identities and producing "a displacement of place by space" (Brown et al., 2000 , p. 438). In this context, music legends are agents in the cultural diffusion of cultural values and music contributes to the spatial diffusion of various musicians based on consumer demand, turning them into famous artists, thus constructing iconic music legends.

Through digital recordings, broadcasting, internet and media, tours and live concerts, consumers and music fans have been always connected to their favourite artists. Therefore, the cultural diffusion of popular music appeared as a multi-channelled process (Waterman, 2006) (re)producing social systems through the spatial distribution of music, musical activities and performers. Hence, music hearths, music diffusion, geographic delimitations of areas with certain musical traits and musical traditions connected to place and identity remain meaningful (Kong, 1995) and could be associated with different music legends. The abovementioned elements have been incorporated into a global culture with music production, distribution and consumption sustaining iconic music legends that are now recognised and in demand worldwide. Against such a background, a key merit is given by music industry expanded through the rapid emergence of creative industries (Leslie \& Rantisi, 2017). They are part of economic development and assumed an important role in many global economies over a period of significant economic evolution across the twentieth century (Florida \& Jackson, 2010; Hracs et al., 2016), governed by technology, tastes of music consumption, commercialism and music marketisation (Smith, 1997).

Musicians became unique actors, their music being an important economic resource for social, cultural and economic development (Florida \& Jackson, 2010; Hudson, 2006). From a classic creative industry, popular music has become broader and produced intangible products, involving cultural producers, agents and various market actors (Caves, 2000; Florida et al., 2010). Through the global cultural flows and spatial networks (Kearney, 2010; Lovering, 1998), they turned popular music into an agent in the spatial distribution of music values, producing important music performers and iconic music legends. Their music penetrated by global structures and spatio-temporal mobility reflects the economic importance of arts and music on a global scale (Brown et al., 2000; Banks et al., 2000). That is because music is always in a state of movement. It travels through commercial activities and artists' tours (Finn, 2011; Lashua et al., 2014), being (re)produced by cultural events and economic networks. Music became a mobile cultural expression (Connell \& Gibson, 2004) sustained by music legends travelling worldwide and sharing their music (see Milburn, 2017). Therefore, "music and fans, collectively, share their common musical tastes" (Bennett \& Peterson, 2004, p. 1) in specific places, creating authentic music scenes and music legends. This aspect is particularly visible regarding legendary musicians who perform worldwide.

Music scenes appear to be music locations for the music industry (Florida et al., 2010; Florida \& Jackson, 2010; Kruse, 2009a) and for the production and consumption of music (Kong, 1995; Kruse, 2005). They are places for music practices and performances illuminating authentic connections with mainstream music, audience demand and famous musicians (see Forman, 2002; Krims, 2007). As live music is a key feature in contemporary society (Frith, 2012), music scenes are sites of live performances of living legends, where producers and consumers meet for production and consumption to take place. They frame regions spatially delimited by those large markets offered by cities and regions where artists perform (Florida et al., 2010). Furthermore, music scenes are produced by the concentration of musicians in geographical centres (Currid, 2007), providing opportunities for unique artistic goods to be produced and consumed in certain places and in different ways, articulating the geography of inequality (Lloyd \& Clark, 2000; Smith, 1997). As music scenes, cities are homes and venues for global 
music legends and often places to which global music icons are embodied identifying themselves in many ways through fans, through music production, or through feelings framed by the various senses of belonging. Furthermore, music scenes are sites of music consumption connected to specific artists and to communities' demand for specific musicians perceived as music legends (Glaeser et al., 2001; Johansson \& Bell, 2009; Kearney, 2009).

Against such a background, iconic music legends are prominent artists, whose lives, careers and songs have constructed important traditions in music mainstream, setting their performances on the world's cultural map. According to Beauregard $(2002$, p. 3), "every musical decade has embraced its superstar acts that generated iconic music legends, branding the global popular music culture stardom" and they must be studied to gain new understandings into the pathways shaped by their music in world's cultures. In spite of being only emblematic figures of popular music, these artists are legends through their commitments to other areas across the social, cultural, economic and political fields. Iconic music legends have influenced world cultures, people's way of life and regional and local communities. They are universally recognized through performances, sales, awards and humanitarian involvement. Iconic music legends are devoted to their audiences and fans and contribute to the production of music scenes as veritable locations for live performances. Concerts, awards, chart statistics and in-demand performances are important features in the music legends construction. Since music and global audience produced legends, in 2011, media brand Billboard established the Billboard Icon Award to recognize singers and their contribution to global music culture. ${ }^{2}$ The Icon Award is the highest form of worldwide recognition an artist can receive, often marking a career that has spanned decades and is deserving of respect and admiration. Only a few select performers have received the Icon Award, with Céline Dion joining the list in $2016 .^{3}$ Even though she was already considered a music legend, this recognition officially turned this artist into a worldwide iconic music legend with a global recognition.

\section{METHODOLOGY}

Since case studies remain an important facet in music geography research (see Anderson, 2004; Cohen, 1991; Milburn, 2017), this study focuses on Céline Dion artist, a global music living legend, with an outstanding contribution to music and to global popular music culture. The research was conducted between 2016 and 2019. ${ }^{4}$

The first step of this investigation was an inventory of available data concerning Dion's musical career. A huge database of spatio-temporal information was uncovered. ${ }^{5}$ It was approached

${ }^{2}$ According to Billboard www.billboard.com, Accessed September 2017.

${ }^{3}$ Legends officially recognized: Neil Diamond, Stevie Wonder, Prince, etc.; see https://www.youtube.com/watch?v=sIJbFawC, Accessed September 2017.

${ }^{4}$ The starting point of the research was the time after Dion officially received the Icon Music Award by Billboard, May 2016.

${ }^{5}$ The analysis of statistic data was an attempt to comprise the data on the artist's albums, tours and concerts as accurately as possible. Due to various sources of information providing different data or due some inexact values during the data processing, some minor errors may occur $( \pm 0-5 \%)$, without altering neither the main spatial and temporal results at different geographical scales, nor the general findings of the study on the outstanding contribution of the artist to music and global popular music 
through a set of methods. The topic's complexity required geographical methodologies that overlap with other fields of research (Smith et al., 2017). Therefore, a multi-method approach was used. In line with the general aim of the investigation of the career evolution, from the initial cultural hearth of Quebec to a musical involvement with a global reach, biographic analysis with autobiographies, biographies and discourse analysis related to narrative research (Roberts, 2002; Shuker, 2016) provided meaningful information on Dion's artistic life, involvement and musical commitments. Hence, biographic textbooks, video and online biographic documentaries were useful. Then, quantitative research, as a key method in gaining accurate findings in music geography (Cohen, 1995; Florida \& Jackson, 2010), was used.

Statistical data analysis based on multiple variables was useful in acquiring objective results to assess Dion's contribution to global music. The statistical method provided critical, explanatory and correlational analysis (bivariate correlative research). The main variables considered from available sources were international tours and concerts examined per continents and countries, albums sold per continent, home videos, and tickets sold, the music scenes (as places of performances) and the gross sales. In addition, the spatial distribution of the artistic activities from Dion's hometown to far across the globe was examined. The data was mapped highlighting that musical cartographies and maps remain relevant to study this phenomenon from a geographical perspective (see Finn \& Lukinbeal, 2009; Florida \& Jackson, 2010). The maps were realised using ArcGIS Desktop 10.3.

Quantitative cartographic methods using graduated symbols were used, providing a representation of worldwide spatial distribution of concerts per continent and country and highlighting each music scene in which the artist performed. The qualitative research was based on the internet resources and digital environment using visual methodologies as key methods in geographical approach on music (Connell \& Gibson, 2004; Rose, 2016). The research made use of the internet since its "potential to increase the connectivity across the world" (Verboord \& van Noord 2016, p. 59), contributes to the popular music diffusion thus reaching to a global audience. Specifically, YouTube, online videos and materials, suggested by Chenail (2011), Rogers (2010) and Rossetto \& Andrigo (2017), were used to assess Dion's musical contribution. Special attention was paid to the official YouTube channel of the artist and to YouTube statistics included in Social Blade database. Through these channels the artist's most highly ranked songs in online videos considering the numbers of viewer 'likes' and comments as representations of the cultural perception and popularity were analysed. A number of 18 videos were studied. Given the extraordinary amount of data available online, selecting relevant media materials and data was difficult. ${ }^{6}$

culture. Since different albums are still on sale in the present days and the album sales are an ongoing process it is difficult to determine certain and complete results on the total album sales.

${ }^{6}$ Internet search returned in October 2017 an enormous amount of results: 14,100,000 results including $5,890,000$ video materials, 186,000 news and 45,100 texts. In December 2019, Internet search returned an approximate value of $97,600,000$ results in 0.49 sec., 40,600 000 videos in 0.19 sec., and $8,050,000$ news in $0.13 \mathrm{sec}$. The selection was difficult. However, 50 video clips, 100 live performances, 30 documentaries, and 30 TV shows have been examined. Articles from specialized magazines, documentaries and concerts produced by Laporte \& Snyder, 2010; Lamourex et al., 2008; Lamoureux \& Snyder, 2009, 2010, 2013, provided relevant information. Statistic data processed in the study and available up to 2014 was selected from http://www.celinedioncharts.com/online accessed during the research. The maps are based on https://www.setlist.fm/ with data available in 2016. Internet resources and websites with data and information were approached under the fair use 
To portray Dion's music and to understand its meanings and messages, discography and videography analysis (with English and French versions) helped with careful consideration of the messages that the artist has attempted to convey to her global audience. Therefore, phonographic methods through listening investigation, songs research and lyric analysis - as suggested by Carney (1998b), Gallagher and Prior (2014), Gallagher et al. (2017) - provided important information. ${ }^{7}$ This helped in understanding how this iconic music legend gained her unique international music stardom mirrored in the outstanding contribution of the artist to global popular music culture and in the musical meanings of her performances. Based on this methodology, the next sections unveil the main findings.

\section{RESULTS AND DISCUSSION}

From the Quebequois dream to a musical career with a global reach: music, identity and place through a biographic analysis

Born in Charlemagne near Montréal in 1968, Dion first expressed her wish to become a singer at the age of five. When she was twelve, she sang to her first official audience (Caraman-Fotea \& Nicolau, 1999). Music has been Dion's passion for as long as she can remember, ${ }^{8}$ and her native town was the first cultural hearth from which her music started to resonate. To investigate Dion's outstanding contribution to global music, one must look at it in three separate stages that shifted different music types, identities and places.

The first stage (1980-1990) stands on the French identity diffusion and national music culture enrichment and reveals multiple changes in music industry when Dion appeared on the Canadian music scenes. Her first albums were released in French, and in a short period of time, her music expanded in Europe (France) and Asia (Japan). These were some of the regions where she would go on to register huge success. A distribution contract through EMI, diffused her music in Europe with the first single released in 1982. Her performance at the World Popular Song Festival in Tokyo, where Dion represented France (organized by the Yamaha Music Foundation) won a Gold Medal and a special prize. This event was watched at that time by 115 million TV spectators. This enormous success under the French identity was acknowledged by the Quebecer authorities with Dion receiving the local mayor's recognition for the great honour offered to Canada, Quebec and Charlemagne (Beauregard, 2002; Dion \& Germain, 2000). Thereby, this space officially became the cultural hearth of Dion's French music.

In 1983, Dion represented Canada at MIDEM (International Market of Disc and Musical Edition, Cannes) and became the first Canadian artist to win a global award. Four albums released in Canada, a French single and four ADISQ awards (the Quebecer version of the Grammys) completed Dion's contribution to French popular music, which was then diffused in Germany. A number of new albums and singles were released in Canada and France, distributed by Trans-Canada Music Company and she won five Felix Awards - the most anybody had won to date. Even though she sold almost one million albums in Quebec, CBS Records (Toronto) had not heard of her. This was a consequence of national cultural and

regulation since online public data can be used without copyright permission in research, educational purposes and scholarships with non-profit and non-commercial aims.

${ }^{7}$ Based on the author's personal collection of materials (original albums and DVDs).

${ }^{8}$ As Dion officially admitted; see https://www.youtube.com/watch?v=cJXvDFN-pxE, Accessed July 2017. 
political tensions since English Canada ignored the cultural values of French Canada and viceversa (Beauregard, 2002; Hurley, 2011). In 1987, a contract for an English album was signed to be released under Carrer (CBS). A large tour with 42 live performances followed in Quebec, and Dion's English album was distributed in Europe (Denmark, Spain and Germany). The French-Canadian chanteuse started her English performances by including English songs in her repertoire, which would ensure a larger audience and new music markets. Attending the 1988 Eurovision Contest in Dublin (Ireland), Dion represented Switzerland and won, watched by 600 million European TV viewers. With all of this success, the UK and Germany had still not adopted her songs. However, she won four ADISQ Awards in Canada. In 1990, CBS Recording released Dion's first English album (Unison) and sold two million copies (Beauregard, 2002).

A new stage began in 1990 and continued until 2000, which transformed Dion into an international singer with an outstanding career. This stage saw massive internationalisation of her music through different channels: tours, live performances, new albums with impressive sales, media and broadcasts. The continuous development of music industry contributed to Dion's success in the coming decade. CBS was bought over by Sony International to become Sony Music Canada with a branch in Quebec (Sony Musique). In 1991, a \$10M contract - the biggest for any Canadian to date at that time - was signed for five new albums over the next 10 years. It was fulfilled in less than five, and a new contract followed. This decade brought the most important successes for Dion all-across the globe (including the UK and Germany), with her music officially acknowledged in the Anglophone music markets. The first large US tour started in the 1990s with other tours completed in Asia, Australia and Europe. New singles and another English album, The colour of my love, were released worldwide together with a French album and a special Christmas one. In 1994, Dion recorded a huge success, with The power of love holding the No. 1 position on the Billboard Charts for four weeks. ${ }^{9}$ In the same year, her sold-out shows at the Olympia Music Hall in Paris ended with a recording of a live album, $A$ I'Olympia (Glatzer, 2005; Gerra, 2007; Beauregard, 2002; Jones, 2001). Dion has continued to perform worldwide in French, promoting her native language through her music. Consequently, the important French album released in 1995 (D'Eux) became the best-selling Francophone album with a huge impact in France and Canada. Thus, Dion was acknowledged as the No. 1 artist in France and another French album was released. In Japan, huge sales were recorded by To love more, one of the artist's most emblematic hits (Laporte \& Snyder, 2010; Dion \& Germain, 2000).

In 1995, Dion was the biggest selling artist in the French and English languages and in 1996 new tours and live performances were held at international music scenes including Marseille, Lyon, Paris, London and Brussels. The new album, Falling into you, was released worldwide alongside the single of the same name. The album was a best seller in almost every country with its songs ranking highly on the Billboard charts. A new worldwide live tour started with 148 concerts from America to New Zealand covering every important music scene of the world. Dion sung not only in French and English, but also in Spanish and German, unveiling a multicultural approach in her artistic performances that in the US culminated in more than 250 concerts. Two short concerts were held in Las Vegas at the Caesar Palace, which would go on to host her emblematic residency show. In addition, many European cities hosted Dion's live concerts across France, Belgium, UK, Germany, Netherlands, Sweden, Italy, Norway, Switzerland and cities as Paris, London, Dublin, Berlin, Milan alongside other many European cities became important music scenes both for the artist and for Dion's fans. The album Falling

9 According to https://www.billboard.com/articles/columns/chart-beat/7743569/celine-dion-biggestbillboard-hot-100-hits, Accessed July 2017. 
into you held the number one position on the Billboard chart for three weeks. The French music industry also achieved huge international recognition with the albums Live à Paris, $D^{\prime} E u x$ and Falling into you. More than 1.5 million spectators attended Dion's concerts and at the Opening Ceremony of the Atlanta Olympics in 1996 where the artist performed her The power of the dream anthem in front of 200,000 spectators and 3.5 billion TV viewers. It was a huge international performance for a French singer. The tour that opened in 1996 continued accompanied by other epic representations in Japan, Korea, and Montreal, performing on the most important music scenes across four continents (Beauregard, 2002).

Dion's musical contribution made her next studio album the most anticipated album in 1997. Let's talk about love overlapped with the release of the Titanic movie, which brought further international success. The song My heart will go on - the theme song of the motion picture became one of the artist's most important hits, registering huge success worldwide. The song also recorded the largest radio audience ever, being No. 1 all around the globe. The reason stands on the emotional love message of the song that touched millions of people worldwide and on the exciting movie multiple awarded at that time unveiling on the background of Titanic disaster a true and dramatic love story. Besides, love appears to be as the major topic in Dion's songs. The true love expressed and shared through the moving music and the moving voice of the artist is the core argument for people, and fans appreciate Dion as a unique songstress. Following this huge success, the artist performed at the Oscars Awards Ceremony for a third time. A new world tour then started, spanning 15 months with more than 2.3 million tickets sold. At the same time, a new French album was released. Dion's outstanding contribution to global music cultures turned her into an international artist in the global popular music. Thereby, to frame her contribution in a single product, the album All the way$A$ decade of songs was released with its content varying from "one region of the world to another, to reflect the songs that had more impact in some regions" (Beauregard, 2002, p. 24). Two important moments were then designed: an impressive event in Montreal on 31 December 1999 - The Millennium Concert - to which fans from all over the world attended, tuned in on TV and the TVA Network; and a break in her musical activity. The major reason for the break was her desire to become a mother, which she described as the most important thing in life (Laporte and Snyder, 2010). ${ }^{10}$ It happened in 2001, when her first child was born (Dion \& Germain, 2000).

Following this period, a new artistic journey started and has not stopped despite various changes in the artist's life and in the global music industry. The key features of this stage were: new studio albums and compilations; a new residency show in Las Vegas - a real music scene for the fans and tourists from round the world who have the chance to see Dion in person there (see Lamoureux et al., 2008) and a new epic world tour, Taking chances (2008-2009), with Dion being joined by all her music team and family. A special documentary was released then to unveil the most important cultural issues of the tour and Dion's own personalityexperiencing people, places and cultures through music. The film portrays the cultural traits of Dion's behaviour related to different cultures of the world. Place, identity, peace, human rights, politics, love, cultural diffusion and diversity, true human values, music perception and related themes were illustrated, triangulating Dion's artistic and personal involvement in global music cultures. Humanitarian commitments, philanthropic endeavours, care, respect and unconditional love for people, cultures, nations and world identities are some of the key

${ }^{10}$ See also https://www.youtube.com/watch?v=yRsoPiKR1bY;

https://www.youtube.com/watch?v=oLcq3W1cKyc, Accessed July 2017. 
features that define the artist in the contemporary culture of global popular music (see Laporte \& Snyder, 2010; Lamourex \& Snyder, 2009, 2010, 2013).

In 2011, Dion's Vegas show was re-launched, with the artist now a mother of three children. ${ }^{11}$ Between 2011 and 2019, live concerts and performance were held in Las Vegas, the artist's long-run residency show ending in 2019, after 16 years of live performances with 1,141 concerts, shared with more than 4 millions of fans (Katsilometes, 2019). At the same time, Dion continues touring in 2016 and 2017 in different European countries with multiple soldout shows. Since 'the show must go on' - a powerful motto in the artist's life (see Lamourex \& Snyder, 2010) - a new regional Asia-Pacific tour was held in the summer of 2018 and new musical projects started: a new large world tour designed for 2019-2020 and a new English album released at the end of 2019 (both of them under the title Courage).

All these demonstrate that Dion continues to represent one of the most demanded artists in the world, and the artist, with a legendary career spanning almost four decades, continues to share her music and her love with millions of fans worldwide being on top positions in the contemporary music industry. That is because the people and fans all over the world demand both for Dion's music and Dion artist. In this respect, the singer continues her musical commitments with the fans and the music and this artistic involvement goes on.

\section{Towards a statistical analysis}

Turning the brief biographic investigation to statistical analysis, the data show relevant issues of Dion's career and the impact of her music on global music cultures. The first investigated item focuses on her albums. Table 1 shows worldwide albums sales (French and English). Of these, 26 were studio albums ${ }^{12}$ - a real record for an artist. Due to sales data, all albums were internationally awarded with tens of millions of copies sold worldwide. English albums account for more than 50 percent of the gross sales. They include the most important songs placed in the top positions of the international music charts. ${ }^{13}$ Of these, the most relevant remains Billboard, the world music Bible of all times (Beauregard, 2002). The French albums are detailed in Table 2, showing the same patterns of success. Statistics on album sales at a regional scale (Table 3 ) reveal the artist's sales in North America, with over 83 million copies sold in the US and Canada. These massive sales are due to most Dion's fans being from her native Canada and with the US becoming her country of residence (Laporte \& Snyder, 2010). Europe is the second top-selling continent, with sales exceeding 50 million. The impressive sales in France, UK, Germany, Switzerland, Austria, the Netherlands, Ireland, Norway, Sweden, Denmark, Finland, Spain, Italy, Portugal, Poland, Hungary and Belgium are justified for many reasons.

Firstly, the music industry and media development were responsible for the spatial distribution of Dion's music, as some of the most important global music companies supported the singer's management. CBS (Canada, France), Columbia and Carrere (France), Epic (UK, Japan), Sony Musique Canada, Sony 550 US and Sony Music are all international companies with an important role in the global economy of music (Shuker, 2016) and made a decisive contribution in the spatial diffusion of Dion's albums. Secondly, consumption of Dion's music and public demand

${ }^{11}$ See https://www.youtube.com/watch?v=oLcq3W1cKyc, Accessed July 2017

12 According to Today Show, available at https://www.youtube.com/watch?v=fYJSMd2gSeA, Accessed December 2016.

${ }^{13}$ According to Billboard, available at https://www.billboard.com/articles/columns/chartbeat/7743569/celine-dion-biggest-billboard-hot-100-hits, Accessed July 2017. 
were determinant, as communities enjoyed the artist both from media channels and live in concert. Overall, Sony Music had and still has a key role in Dion's music production and in the spatial diffusion of the artist's albums. In addition, an outstanding contribution in Dion's successful career had René Angélil as Dion's husband and musical manager.

Table 1: Statistics on albums sales $1981-2014$

\begin{tabular}{|c|c|c|c|c|c|}
\hline & Album title & $\begin{array}{c}\text { Year / } \\
\text { Released }\end{array}$ & $\begin{array}{l}\text { Copies sold } \\
\text { in millions }\end{array}$ & Percent & Awarded \\
\hline 1 & First French albums & 1981-1990 & 1.3 & 0.73 & YES \\
\hline 2 & Unison & 1990 & 3.1 & 1.74 & YES \\
\hline 3 & Dion chante Plamondon/Dion sings & & & & \\
\hline & Plamondon & 1991 & 1.2 & 0.67 & YES \\
\hline 4 & Céline Dion & 1992 & 5.4 & 3.04 & YES \\
\hline 5 & The color of my love & 1993 & 16.6 & 9.34 & YES \\
\hline 6 & Céline Dion á l’Olympia & 1994 & 0.8 & 0.43 & YES \\
\hline 7 & D'Eux/From them & 1995 & 7.7 & 4.31 & YES \\
\hline 8 & Falling into you & 1996 & 30.3 & 17.07 & YES \\
\hline 9 & Live á Paris/Live in Paris & 1996 & 2.3 & 1.30 & YES \\
\hline 10 & Let's talk about love & 1997 & 32.1 & 18.09 & YES \\
\hline 11 & $\begin{array}{l}\text { S'il suffisait d'aimer/If only love could } \\
\text { be enough }\end{array}$ & 1998 & 3.9 & 2.19 & YES \\
\hline 12 & These are special times & 1998 & 12.1 & 6.81 & YES \\
\hline 13 & $\begin{array}{l}\text { Au coeur du Stade/At the heart of } \\
\text { the Stadium }\end{array}$ & 1999 & 1.2 & 0.69 & YES \\
\hline 14 & All the way... a decade of songs & 1999 & 22.5 & 12.68 & YES \\
\hline 15 & $\begin{array}{l}\text { The collector's series Vol. 1/Tout en } \\
\text { amour }\end{array}$ & 2000 & 2.6 & 1.47 & YES \\
\hline 16 & A new day has come & 2002 & 10.5 & 5.90 & YES \\
\hline 17 & One heart & 2003 & 5.1 & 2.90 & YES \\
\hline 18 & 1 fille\& 4 types & 2003 & 1.4 & 0.81 & YES \\
\hline 19 & A new day - live in Las Vegas & 2004 & 1.2 & 0.69 & YES \\
\hline 20 & Miracle & 2004 & 2.6 & 1.48 & YES \\
\hline 21 & On ne change pas & 2005 & 1.2 & 0.67 & YES \\
\hline 22 & D'elles & 2007 & 0.7 & 0.40 & YES \\
\hline 23 & Taking chances & 2007 & 3.4 & 1.90 & YES \\
\hline 24 & My love. Essential Collection & 2008 & 2.6 & 1.47 & YES \\
\hline 25 & Taking chances world tour & 2008 & 0.4 & 0.23 & YES \\
\hline 26 & Sans attendre & 2012 & 1.4 & 0.76 & YES \\
\hline 27 & Loved me back to life & 2013 & 1.5 & 0.87 & YES \\
\hline 28 & Un seule fois & $2013 / 2014$ & 0.1 & 0.06 & YES \\
\hline 29 & Other albums & 2014 & 2.3 & 1.31 & YES \\
\hline \multicolumn{2}{|c|}{ TOTAL } & $1981-2014$ & 177.7 & 100 & \\
\hline
\end{tabular}

Source: http://www.celinedioncharts.com/byalbum.html, Accessed May 2017. 
Table 2: Statistics on French album sales $1981-2017$

\begin{tabular}{|c|c|c|c|}
\hline Album title & $\begin{array}{c}\text { Year/ } \\
\text { Released }\end{array}$ & Copies & $\begin{array}{l}\text { Awarded } \\
\text { Certified }\end{array}$ \\
\hline La voix du Bon Dieu/The voice of God & 1981 & 50,000 & NO \\
\hline Céline chante Noël/Céline sings Christmas & 1981 & 25,000 & NO \\
\hline Tellement j'ai d'amour/l have so much love & 1982 & 125,000 & YES \\
\hline Les chemins de ma maison/The paths to my home & 1983 & 100,000 & YES \\
\hline Du soleil au coeur/Sunshine in the heart & 1983 & 50,000 & YES \\
\hline Chants et contes de Noël/Songs and tales of Christmas & 1983 & 50.000 & YES \\
\hline Les oiseaux du bonheur/Birds of happiness & 1984 & 50,000 & YES \\
\hline Les plus grands succès de Céline Dion/Greatest hits of & & & \\
\hline Céline Dion & 1984 & 75,000 & YES \\
\hline Mélanie & 1984 & 175,000 & YES \\
\hline C'est pour toi/That is for you & 1985 & 50.000 & YES \\
\hline Céline Dion en concert/Céline Dion live & 1985 & 50,000 & YES \\
\hline Les chansons en or/The Golden songs & 1986 & 150,000 & YES \\
\hline Incognito & 1987 & 500,000 & YES \\
\hline The best of... & 1988 & 100,000 & YES \\
\hline Dion chante Plamondon/Dion sings Plamondon & 1991 & $2,000,000$ & YES \\
\hline Les premièrs années/The first years & 1993 & 250,000 & YES \\
\hline Céline Dion a l'Olympia/Céline Dion at the Olympia & 1994 & $1,500,000$ & YES \\
\hline D'Eux & 1995 & $8,000,000$ & YES \\
\hline Céline Dion Gold & 1995 & 250,000 & - \\
\hline Céline Dion Gold 2 & 1995 & 75,000 & - \\
\hline Live á Paris/Live in Paris & 1996 & $3,000,000$ & YES \\
\hline C'est pour vivre/It's to live & 1997 & 50,000 & YES \\
\hline The Collection $1982-1988$ & 1997 & 50,000 & - \\
\hline$S^{\prime}$ il suffisait d'aimer/If only love could be enough & 1998 & $6,000,000$ & YES \\
\hline Au couer du Stade/At the heart of the Stadium & 1999 & $1,000,000$ & YES \\
\hline 1 fille $\& 4$ types & 2003 & $1,400,000$ & YES \\
\hline On ne chage pas & 2005 & $1,200,000$ & YES \\
\hline D’elles & 2007 & 700,000 & YES \\
\hline Sans attendre & 2012 & $1,400,000$ & YES \\
\hline Un seule fois & $2013 / 2014$ & 100,000 & YES \\
\hline Encore un soir/One more night* & 2017 & $1,500,000$ & YES \\
\hline Un peu de nous** & 2017 & 80,082 & YES \\
\hline Total & $1981-2017$ & $30,105,082$ & \\
\hline
\end{tabular}

Source: Beauregard, 2002; http://www.celinedioncharts.com/byalbum.htm Accessed May 2017. 
Table 3: Statistics on album sales per continent $1991-2014$

\begin{tabular}{|c|c|c|c|c|c|c|c|}
\hline \multirow{2}{*}{ Album title } & \multirow{2}{*}{ Year } & America & Europe & Asia & Africa & Oceania & Total \\
\hline & & \multicolumn{6}{|c|}{ Album sales (in thousands) } \\
\hline Unison & 1991 & 2,425 & 500 & 100 & 40 & 20 & 3,085 \\
\hline Dion chante Plamondon & 1991 & 400 & 710 & 45 & 35 & 5 & 1,195 \\
\hline Céline Dion & 1992 & 4,705 & 280 & 275 & 80 & 60 & 5,400 \\
\hline The color of my love & 1993 & 8,325 & 4,855 & 2,395 & 300 & 725 & 16,600 \\
\hline Céline Dion á l'Olympia & 1994 & 260 & 400 & 50 & 45 & 5 & 760 \\
\hline D'Eux & 1995 & 1,100 & 6,085 & 150 & 300 & 22.5 & $7,657.5$ \\
\hline Falling into you & 1996 & 15,850 & 8,247 & 3,630 & 1,350 & 1,260 & 30,337 \\
\hline Live á Paris & 1996 & 365 & 1,740 & 100 & 90 & 20 & 2,315 \\
\hline Let's talk about love & 1997 & 15,550 & 10,120 & 4,530 & 1,200 & 745 & 32,145 \\
\hline S'il suffisait d'aimer & 1998 & 790 & 2,675 & 150 & 250 & 25 & 3,890 \\
\hline These are special times & 1998 & 7,550 & 1,849 & 2,050 & 500 & 150 & 12,099 \\
\hline Au Coeur du Stade & 1999 & 110 & 935 & 75 & 100 & 10 & 1,230 \\
\hline All the way a decade of songs & 1999 & 11,950 & 5,581 & 3,750 & 900 & 360 & 22,541 \\
\hline The collector's series Vol. 1 & 2000 & 1,375 & 765 & 300 & 150 & 25 & 2,615 \\
\hline A new day has come & 2002 & 5,050 & 3,603 & 975 & 600 & 255 & 10,483 \\
\hline One heart & 2003 & 2,775 & 1,498 & 475 & 300 & 100 & 5,148 \\
\hline 1 fille\&4 types & 2003 & 238.14 & 1,020 & 75 & 100 & 10 & 1,443 \\
\hline A new day: live in Las Vegas & 2004 & 699.1 & 329 & 100 & 80 & 15 & $1,223.1$ \\
\hline Miracle & 2004 & 1,345 & 540 & 100 & 100 & 45 & $2,630.5$ \\
\hline One ne change pas & 2005 & 220 & 820 & 75 & 60 & 10 & 1,185 \\
\hline D’elles & 2007 & 240 & 388.5 & 40 & 35 & 7.5 & 711 \\
\hline Taking chances & 2007 & 1,605 & 1,123 & 360 & 200 & 95 & 3,383 \\
\hline My love: Essential collection & 2008 & 960 & 1,331 & 245 & 50 & 21 & 2,607 \\
\hline Taking chances World Tour & 2008 & 231 & 126 & 30 & 20 & 7.5 & 415 \\
\hline Sans attendre & 2012 & 310 & 971 & 35 & 30 & 5 & 1,351 \\
\hline Loved me back to life & 2013 & 620 & 781 & 45 & 80 & 21 & 1,547 \\
\hline Une seule fois & 2013 & 21 & 78 & 10 & 5 & 1 & 115 \\
\hline Total & & $83,694.74$ & $57,350.5$ & $20,165,000$ & 7,000 & $4,025.5$ & $174,111.24$ \\
\hline
\end{tabular}

Source: Processing data according to http://www.celinedioncharts.com/byalbum.htm, Accessed May 2017.

Beyond the market reasons, Europeans recognized part of their cultural identity in Dion's music, which acted as a driving force for consumption, especially in France and in countries where the French language is spoken. Following the release of English albums, there were no borders between Dion's music, people, audience, spaces and places. This is demonstrated by strong sales in South Africa, Asia, Australia and New Zealand. The reason stands on the cultural and language globalisation, with these regions being either areas where English is spoken or regions where, in spite of the different national languages, English appears as a universal way of communication through music. This also explains Dion's music consumption in other language areas under the contemporary cultural globalization.

Globalisation flows ensured the spatial diffusion of Dion's music in many countries, even though statistical information for most of them is not available due to various reasons including political systems (Eastern Europe, South America), cultural differences and economic 
status (Asia), reduced sales in some regions, music piracy, and the huge influence of YouTube (see Hui \& Png, 2003). Sales in Switzerland, Ireland and France are consequences of Dion's attendance at Eurovision and other performances, these countries being the European cultural hearths of her music, with important communities of fans. In the same vein, Asia discovered Dion since she won the Yamaha Contest in Japan. Dion's music has spread to every continent, reaching out to people of different cultures and identities, with all of them resonating with the universal expression of her music. Even though according to available data showed in Table 1 and Table 3 that counts over 200 million albums, overall, Dion has sold over 250 million albums worldwide as of 2016, ${ }^{14}$ making her the biggest female artist of all time - a true legend in global music cultures ${ }^{15}$ and a singer with one of the most famous voices in the world. ${ }^{16}$ The pattern of how Dion became successful around the world based on the album sales is argued by the massive involvement of the music companies in the diffusion of the albums all around the world where the artist made relevant communities of fans. This is arguable by the high rates sales of the most relevant albums from America to Asia and Oceania. Table 3 illustrates this pattern of the artists' global success that can be related to the tours data unveiled in table 4. The most relevant tours all-across the world were close connected to Dion's new released albums to share and promote globally the music from the native places of the artist to far across the planet (from America to Australia and New Zealand). This fits to the new released album Courage in 2019 accompanied by a world tour from America to Europe and Middle East.

The Pearson correlation provides a high rate (0.901) between albums sold and number of concerts per country with the US, Canada, France, the UK, Japan and Australia being positioned in the top ten countries where the artist has performed (Figure 1). A similar value (0.9281) establishes a correlation between albums sold and tickets sold (Figure 2). Statistical correlation argues that Dion's tours and concerts were produced in different countries, where she was in demand, experiencing people and cultures and their diversities. Dion's in demand music and performances are argued by the historic residency show from Las Vegas, a sold out spectacle for four years in a row, ${ }^{17}$ as her European tours from 2016 and 2017 were, with multiple sold-out shows in music scenes including Paris, Avers, Montreal, Quebec, etc. ${ }^{18}$ These patterns illustrate the high correlation between the number of concerts and grossing sales value in 2014, with a rate of 0.9467 (Figure 3).

A comparative approach between statistics of album sales and the live-concerts and tours in the last decade illustrate a decreasing trend of the album sales in favour of concerts and liveperformances. This is because the artist always paid attention to live artistic commitments to the fans, people and audience, involving live concerts thus ensuring continuously a direct contact between the singer and the fans and audience. On the other hand, this is argued by the artist's passion for live singing in the front of the people, either in her musical residency or live in concerts and different other events. Adopting and practicing always live performance

\footnotetext{
${ }^{14}$ According to Today Show 2016, Sony Music, 2019 available at https://www.sonymusic.co.uk/news/2019-11-15/celine-dion-releases-new-album-courage; other source mention 185 million records worldwide; see https://www.youtube.com/watch?v=8KoBHIrcSMs, Accessed July 2017.

15 Ibidem.

16 Idem.

17 Idem, See also Lamoureux et al., 2008.

${ }^{18}$ According to Retrospective 2016 available at https://www.youtube.com/watch?v=wWEOvnMAgvQ, Accessed July 2017 and Retrospective 2017 available at https://www.youtube.com/watch?v=ecU1GnV3mhM, Accessed January 2018.
} 
certainly is the key argument for the music authenticity of the artist, for the artist's respect to her audience and for the public appreciation of a wider audience.

Nevertheless, in line with music industry emergence and based on a professional music management, such an artistic perspective brought to the artist important financial profit. In this regard, the data show Dion's income based on albums sales, world tours and her Vegas show. Statistics reveal increasing an evolution of gross sales between 1983 and 2009, with the A New Day and Taking Chances tours being the most profitable (Table 4).

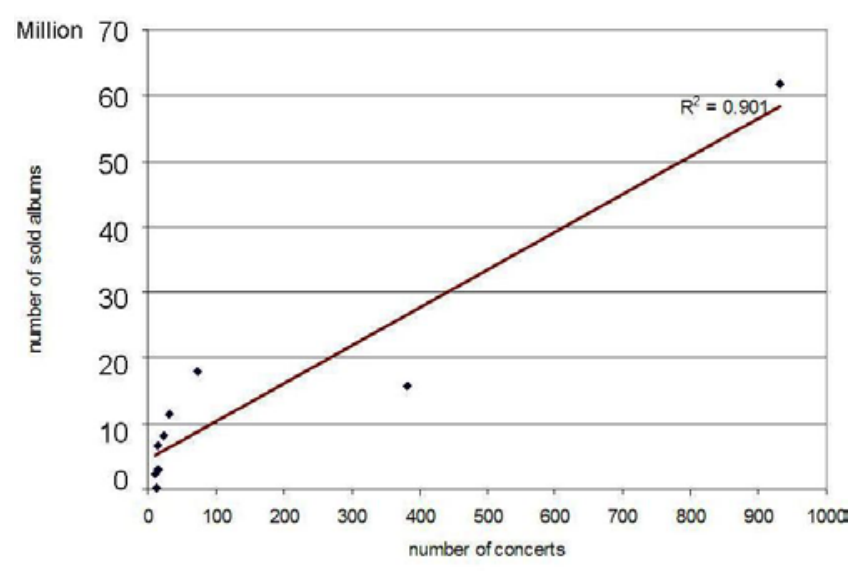

Figure 1: Pearson correlation between sold albums and the number of concerts

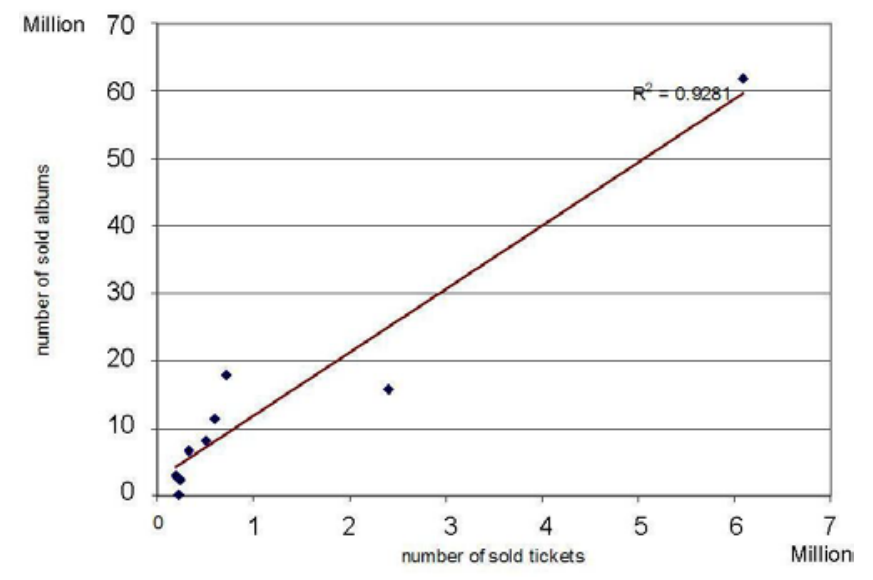

Figure 2: Pearson correlation between sold albums and the sold tickets to live concert

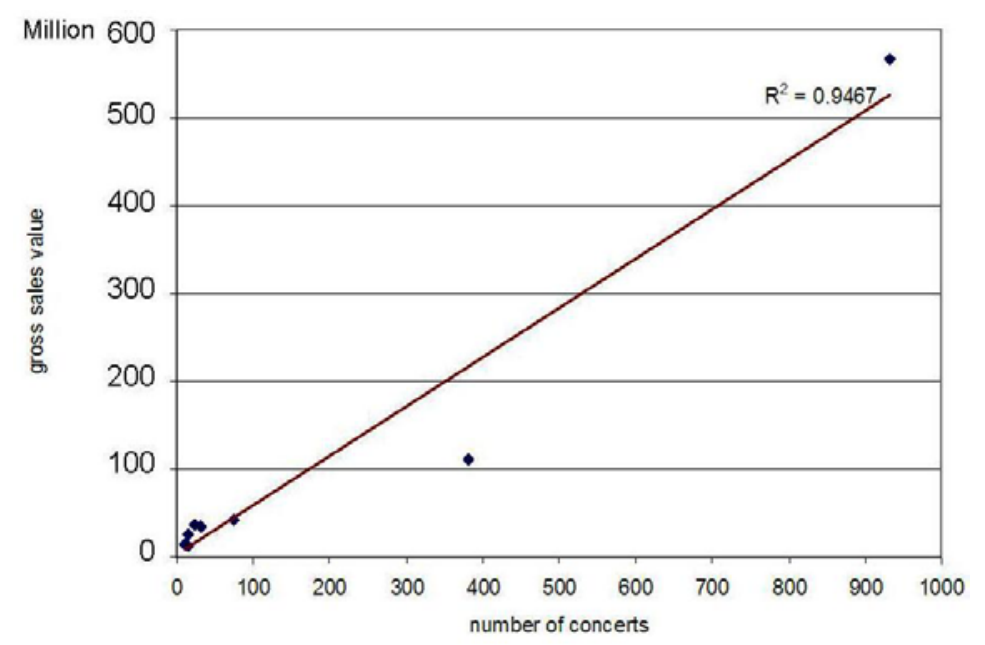

Figure 3: Pearson correlation between gross sales value and the number of concerts in 2014

Since 2011, with Dion's return to Caesar's Palace in Vegas, she has continued to achieve significant income and remained one of the richest artists and one of the most important and wealthiest female musicians in the world based on music industry (Forbes Magazine, 2017; Martin et al., 2016; Matthews, 2018; O'Malley-Greenburg, 2016). In all, the residency show from Vegas cumulated 1,141 spectacles in 2019 with more than four million tickets sold. In addition, an impressive amount of sold tickets was registered in the latest European tours from 2016 and 2017, as well as in the Asia-Pacific tour (2018). In the same vein, the ongoing 
critically acclaimed Courage world-tour received positive reviews being considered as one of the best live shows of 2019 according to Billboard (see Warner, 2019). Beyond this status highlighting the role of music industry in the global popular culture, the most important remains the worldwide fans and people's demand for Dion's live concerts and albums. This question is argued by the different extents of album sales all around the world and by sold-out concerts from America (USA and Canada), to Europe (France) and Asia.

Table 4: Statistical data of most important international worldwide tours and concerts 1983 - 2009

\begin{tabular}{|c|c|c|c|c|c|}
\hline Tour & Year & $\begin{array}{l}\text { Number } \\
\text { of concerts }\end{array}$ & $\begin{array}{l}\text { Tickets } \\
\text { sold }\end{array}$ & Gross sales & Continents and countries \\
\hline $\begin{array}{l}\text { Les chemins de } \\
\text { ma maison }\end{array}$ & 1983-1984 & 40 & 40,000 & 200,000 & America: Canada; Europe: France. \\
\hline C'est pour toi & 1985 & 36 & 45,000 & 400,000 & America: Canada \\
\hline Incognito & 1988 & 75 & 150,000 & $1,500,000$ & America: Canada \\
\hline Unison & 1990-1991 & 75 & 150,000 & $2,000,000$ & America: Canada \\
\hline Celine Dion & 1992-1993 & 74 & 500,000 & $12,000,000$ & America: USA, Canada. \\
\hline $\begin{array}{l}\text { The colour of } \\
\text { my love }\end{array}$ & 1993-1995 & 98 & $1,300,000$ & $33,000,000$ & $\begin{array}{l}\text { America: USA, Canada; Europe: } \\
\text { France, UK, Switzerland, } \\
\text { Netherlands; Asia: Japan }\end{array}$ \\
\hline D'eux & 1995 & 47 & 500,000 & $13,000,000$ & $\begin{array}{l}\text { America: Canada; Europe: France, } \\
\text { UK, Switzerland, Netherlands, } \\
\text { Belgium, Ireland, Germany, } \\
\text { Norway, Sweden, Denmark. }\end{array}$ \\
\hline Falling into you & 1996-1997 & 148 & $2,220,000$ & $80,000,000$ & $\begin{array}{l}\text { America: USA, Canada; Europe: } \\
\text { France, UK, Switzerland, } \\
\text { Netherlands, Belgium, Ireland, } \\
\text { Germany, Norway, Sweden; } \\
\text { Denmark, Italy; Asia: Japan, South } \\
\text { Korea; Australia; New Zealand. }\end{array}$ \\
\hline $\begin{array}{l}\text { Let's talk about } \\
\text { love }\end{array}$ & 1998-1999 & 97 & $2,300,000$ & $133,000,000$ & $\begin{array}{l}\text { America: USA, Canada; Europe: } \\
\text { France, UK, Switzerland, } \\
\text { Netherlands, Belgium, Germany; } \\
\text { Asia: Japan, China; Australia; }\end{array}$ \\
\hline A new day & $2003-2007$ & 723 & $2,930,000$ & $390,800,000$ & America: USA \\
\hline Taking chances & 2008-2009 & 132 & $2,300,000$ & $279,200,000$ & $\begin{array}{l}\text { America: USA, Canada, Mexico, } \\
\text { Puerto Rico; Europe: France, UK, } \\
\text { Switzerland, Netherlands, Belgium, } \\
\text { Ireland, Germany, Finland, Sweden, } \\
\text { Denmark, Italy, Czech Republic, } \\
\text { Poland, Austria, Monaco; Asia: } \\
\text { Japan, South Korea, China, } \\
\text { Malaysia, UAE; Australia; Africa: } \\
\text { South Africa. }\end{array}$ \\
\hline Total & 1983-2009 & 1,545 & $12,435,000$ & $945,100,000$ & \\
\hline
\end{tabular}


The global sales of Dion's home videos show the same pattern of musical success. Table 5 illustrates that more than 5 million of video copies were sold with high rates in America and Europe that brought multiple awards.

Table 5: Statistics on home videos sold worldwide with a continental approach (1991 - 2010)

\begin{tabular}{|c|c|c|c|c|c|c|c|c|c|}
\hline \multirow[t]{2}{*}{ Title / Year } & $\frac{8}{\frac{8}{2}}$ & $\begin{array}{l}\frac{0}{0} \\
\frac{0}{3} \\
\text { 픈 }\end{array}$ & $\frac{\pi}{\frac{\pi}{4}}$ & $\frac{8}{\frac{8}{2}}$ & 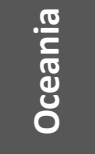 & $\underset{\stackrel{0}{0}}{\stackrel{0}{\circ}}$ & \multirow[t]{2}{*}{$\%$} & \multirow[t]{2}{*}{$\begin{array}{c}\text { Most } \\
\text { successful } \\
\text { country }\end{array}$} & \multirow[t]{2}{*}{ Awards } \\
\hline & \multicolumn{6}{|c|}{ (in thousands) } & & & \\
\hline Unison / 1991 & 80 & 10 & 5 & 1 & 1 & 97 & 1.92 & Canada & $1 G$ \\
\hline The colour of my love / 1995 & 285 & 205 & 100 & 25 & 35 & 650 & 12.89 & USA & $3 P$ \\
\hline Live a Paris / 1996 & 80 & 220 & 50 & 15 & 3 & 368 & 7.30 & France & $4 \mathrm{P}$ \\
\hline Live in Memphis / 1998 & 75 & 72 & 20 & 5 & 2 & 174 & 3.45 & Canada & $3 G$ \\
\hline Au Coeur du Stade / 1999 & 40 & 170 & 40 & 30 & 5 & 285 & 5.65 & France & 1D \\
\hline All the way, a decade / 2001 & 470 & 195 & 150 & 25 & 55 & 895 & 17.75 & Australia & $5 P$ \\
\hline On ne change pas / 2005 & 25 & 120 & 10 & 5 & 1 & 161 & 3.19 & France & $5 P$ \\
\hline Live in Las Vegas / 2007 & 1,015 & 422 & 100 & 150 & 65 & 1,752 & 34.74 & Canada & $3 G, 8 P$ \\
\hline $\begin{array}{l}\text { Céline sur les plaines } \\
\text { Live á Paris / } 2008\end{array}$ & 105 & 53 & 3 & 2 & 0.5 & 164 & 3.24 & Canada & $2 \mathrm{G}, 2 \mathrm{D}$ \\
\hline $\begin{array}{l}\text { Céline. Through the eyes of } \\
\text { the world / } 2010\end{array}$ & 261 & 67 & 30 & 25 & 15 & 398 & 7.89 & Canada & - \\
\hline Other videos & - & - & - & - & - & 100 & 1.98 & - & - \\
\hline Total & 2,436 & 1,534 & 508 & 283 & 182.5 & 5,044 & 100 & & 9G, 25P, 3D \\
\hline
\end{tabular}

Source: http://www.celinedioncharts.com/byhomevideo.html, Accessed May 2017.

Countries from Asia, Africa and Oceania are also places where Dion's home videos were sold. These statistics argue that the music industry is one of the most profitable in the contemporary global economy as artists are in demand by audiences the world over. This is argued by the most successful sales acknowledged with important awards in terms of Diamond, Platinum and Gold prizes. They were multiple times achieved by Dion, from the countries of the native continent to Europe and Australia. The analysis of this issue shows countries as Canada and France prevailing. These awards say important things about relative standing of the artist in top positions of various musical charts in different countries. On the one hand, Canada and France are countries with important communities of fans based on the place attachment of the artist to the native country and to the French people and culture. Then USA remains the country of the artists with relevant fans communities belonging to Anglophone culture. It also fits to the case of Australia where the synthesis album All the way... was repeatedly awarded with Platinum. Furthermore, data highlights Dion's music consumption based on the people's demand related to their cultural and musical preferences.

Within this context, the music consumption on a global scale and public demand for music, regardless of identity, age, religion and ethnicity, remain important (see Laporte \& Snyder, 2010). For instance, considering the first-ever concerts scheduled for Taipei in July 2018, "over 300,000 fans desperately clambered to buy up the 20,000 seats available (...), causing the system to crawl to a standstill for 30 minutes" (Everington, 2018). This shows the huge demand from Dion's fans and the examples could go on. These findings demonstrate Dion's 
outstanding contribution to music on a global scale in spatial terms. To understand geographically these facets, the maps remain relevant, conveying the spatial involvement of the artist through music cartographies across the world. They are disclosed in the next section.

\section{Mapping and representing Dion's outstanding contribution in the global musical culture and beyond}

Mapping Dion's live concerts worldwide from 1984 to 2017 argue the artist's outstanding spatial evolution at a global scale. From Western America to Eastern Asia and from Northern Europe to South Africa (Figure 4), Dion has shared her music and love with hundreds of communities of fans regardless of their location, nationality, cultural identity and ethnicity. As expected, the map reveals her presence in states where she registered important albums sales and large audience demand. Canada (the native country and the cultural hearth for the Dion phenomenon) and the US are the countries with the largest amounts of concerts with more than 1,000 live performances in the US alone. In Europe, France has enjoyed the live performances with over 70 concerts followed by Germany, the UK, and Belgium.

In terms of cultural background, France is the European music hearth of Dion's music due to her Francophone identity. Asia and Australia are also relevant destinations through globalisation flows of popular music. An interesting case is the UAE, with Dubai being a particularly strong music scene in this context. In spite of strong cultural differences, Muslims appear to highly appreciate Dion's music as evidences provided by Taking Chances world tour unveil. This fits in with other states in the region (Iran), also where large communities anticipated live performances in South-Western Asia (see Laporte and Snyder, 2010). Across the world, hundreds of cities and important music scenes have hosted the artist, including Las Vegas, New York, Memphis, Boston (US), Montreal, Quebec, Toronto (Canada), Paris (France), London, Glasgow (UK), Zurich (Switzerland), Tokyo (Japan), Seoul (South Korea), Beijing (China), Sydney (Australia), Johannesburg, and Cape Town (South Africa). They are mapped in Figure 5 , next to other important cities where Dion has performed.

A detailed map of North America (Figure 6) illustrates the spatial distribution of the artist's concerts in Canadian and US cities, emphasizing the two distinctive regions. The Western part of the US stands out with Las Vegas remaining the most important music scene, with a continuous stream of live concerts. For years, Dion has travelled the world, taking her concerts to the communities where her fans live. With the Vegas show, the artist invited fans to join her. And they did, with Dion demonstrating that "no other artist on the planet could claim such a power of attraction", with over 700 sold-out shows and more than 3 million spectators "changing the face of Las Vegas forever and marking show business history for all time" (Lamoureux et al., 2008). As it was already stated, in 2019 , the Vegas residency-show culminated with 1,141 shows and more than 4 million spectators, arguing the in-demand status of the artist (see Katsilometes, 2019). Eastern Canada hosts such emblematic music scenes as Montreal, Toronto, Ottawa and Quebec, the latter being the native region of the artist, the place to which the artist is attached, and the place that she acknowledges as home, which has turned geographically into the cultural hearth of this music legend. The European music scenes relate to French culture and to those countries where the music industry is intensely developed (Figure 7).

Dion's presence is emphasised in places where her music is widely consumed and where European charts have ascribed her music top-rated positions. Paris, London, Dublin and Zurich are emblematic for the artist's tours. Overall, Dion has performed all over the world (with few exceptions, e.g. South America), travelling to share her music with all those communities that 
cherish true cultural values and trust her talent, devotion and passion for music and singing. Economic social and cultural backgrounds played a key role in her presence in particular places. Globalised capitalist cultures and economies have enabled the artist to be present in Western European countries where the music industry has triggered both demand for and the consumption of particular artists' music. Even though Dion has been absent from Central and South-Eastern European countries, perhaps due to post-socialist political and economic transitions and to the slow-go paces in music industry and business development, they remain states where important communities of fans appeared. The ongoing Courage Tour includes for the year of 2020 important live concerts in states as Hungary, Croatia, Romania, Malta, etc., countries where the artist has never performed before. These countries are places and music venues where Dion is also in demand, and, as Figure 8 unveils, the artists' albums are currently on sale in stores specialized in music in cities from Austria, Hungary, and Romania. This statement fits to other countries across Asia, South America, and Africa. ${ }^{19}$ In this regard, Romania with Bucharest as a music venue for various emblematic artists is just an example alongside cities as Zagreb and Budapest in South-Eastern Europe.

Although the artist did not perform live in a number of states - arguing the geography of spatial inequality in music (see Smith, 1997) and generating certain delineated areas where she performed - her music has spread worldwide. Whether cultural, physical, economic and political borders separate these areas, the virtual environment appears more homogenous. The cultural perception of Dion's audience through YouTube channels shows important results. Table 6 illustrates the artist's most important music videos, with various songs viewed by tens of millions of people worldwide.

In all, the artist's videos have been viewed by more than a billion viewers (the $7^{\text {th }}$ part of the global people), who have expressed a total like rate of $95.77 \%$. This demonstrates alongside the YouTube comments' content the global admiration for the artist in the virtual environment, showing that Dion's music has penetrated all spatial, physical and virtual borders. The official YouTube channel of the artist registers 3.67 million subscribers and 2,149,421,608 video views in December 2019. These data are specific only for the official Dion's YouTube Vevo channel without considering the fans and virtual communities YouTube channels, where countless of video uploads are recorded with tens of millions of views. A complete analysis of this data is difficult to make, but at a glance at YouTube channel, Dion appears to be one of the most viewed artists of the world. ${ }^{20}$ Furthermore, according to Social Blade channel, statistics show that the artist has 3.67 of million subscribers, with almost 1 million video views for the last 30 days of December 2019 (958,646). In all, in 2019 December, 30, Dion's YouTube channel recorded 11.471.229 video views with daily average subscribers of $+2.66 \mathrm{~K}$, a monthly average subscriber of $+18.6 \mathrm{~K}$. The average for the last 30 days in December 2019 was $+89 \mathrm{~K}$. The situation of views shows a daily average of $+31,955$, a weekly average of $+223,685$ and for the last 30 days of December 2019, a value of $+958,646$. The prediction data for the next 5 years announce a value of 22,558,046 subscribers and an amount of 25,661,772 views. ${ }^{21}$ These data, correlated with particular statistics unveiled in Table 6 , demonstrate the artists' success and an outstanding contribution to music and global popular music culture both in the physical and online environments.

\footnotetext{
${ }^{19}$ Fans communities are relevant through fan clubs as Céline Dion Latino-America, Brazil, Argentina, Peru, Romania, Russia, Armenia, Morocco, Vietnam, etc. For a full list see https://www.viralvagon.com/facebook/pages/celine-dion, Accessed July 2017.

${ }^{20}$ According to various YouTube channels of different fans and virtual communities and to Dion's official YouTube channel visited in December 30, 2019.

${ }^{21}$ According to Social Blade Channel, accessed online December 30, 2019.
} 


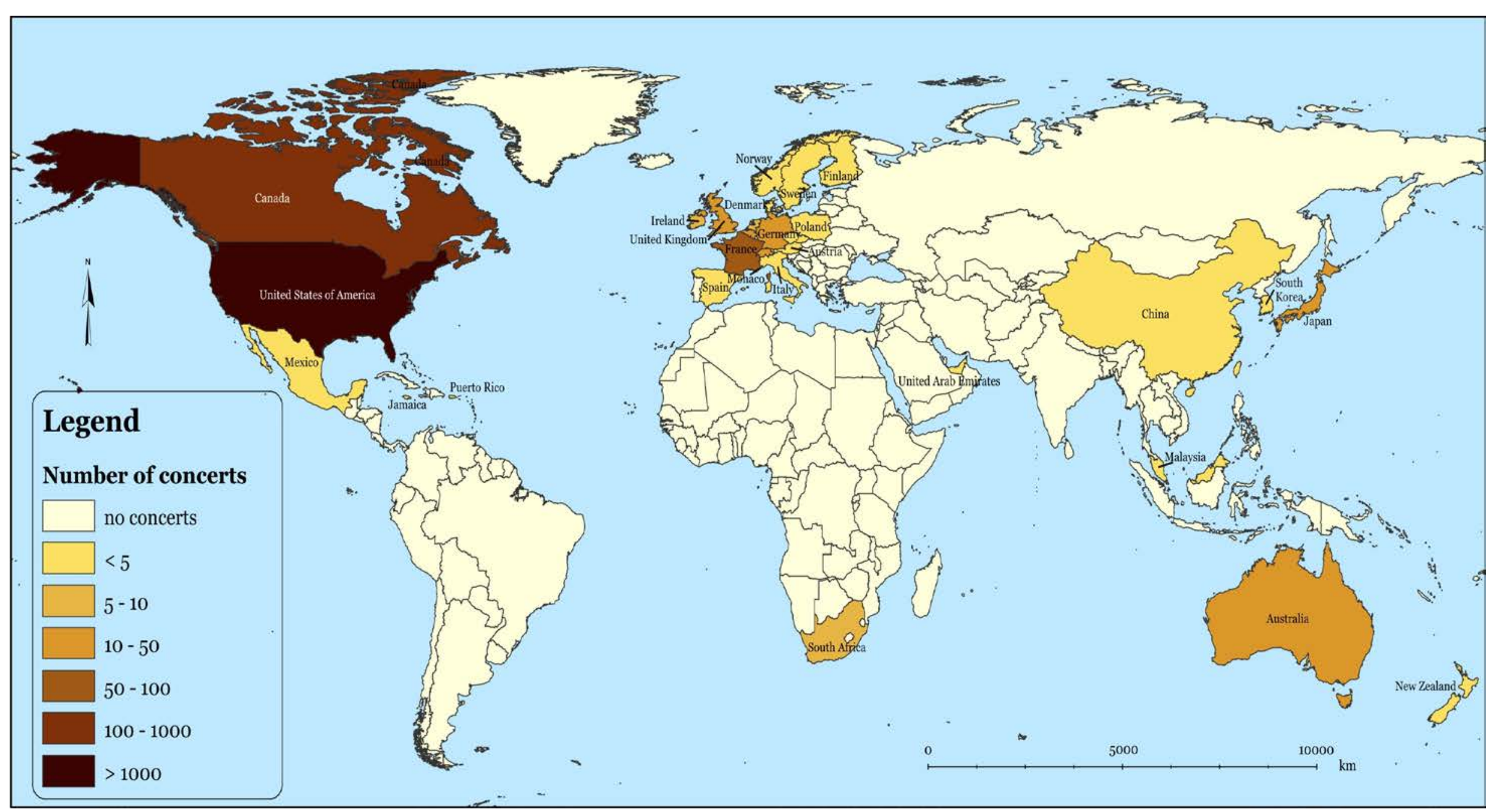

Figure 4: The spatial distribution of Dion's concerts in the world (1984 - 2016) 


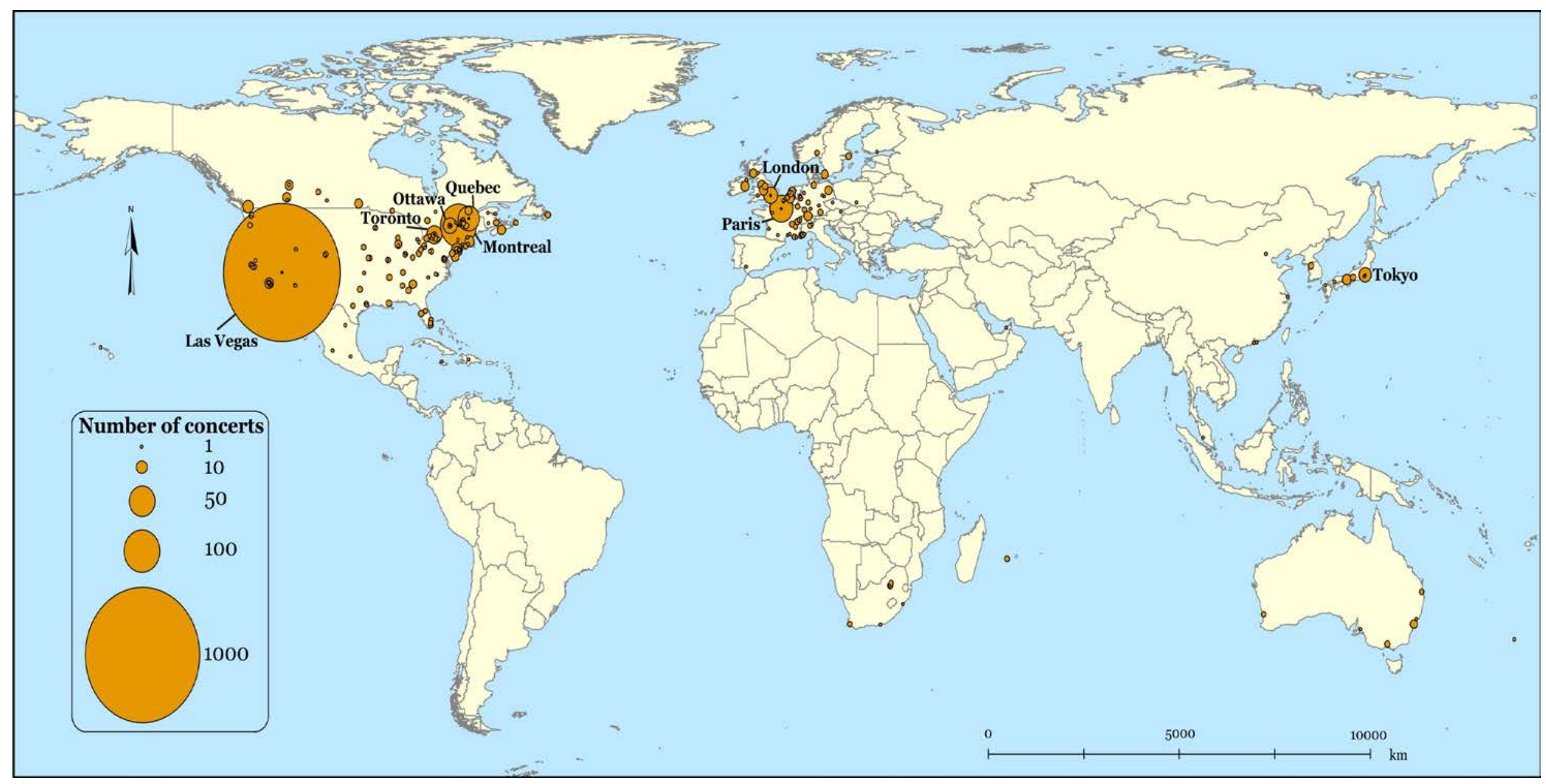

Figure 5: Cities as music scenes where Dion performed (1984 - 2016)

Source of data: Setlistfm, 2017 


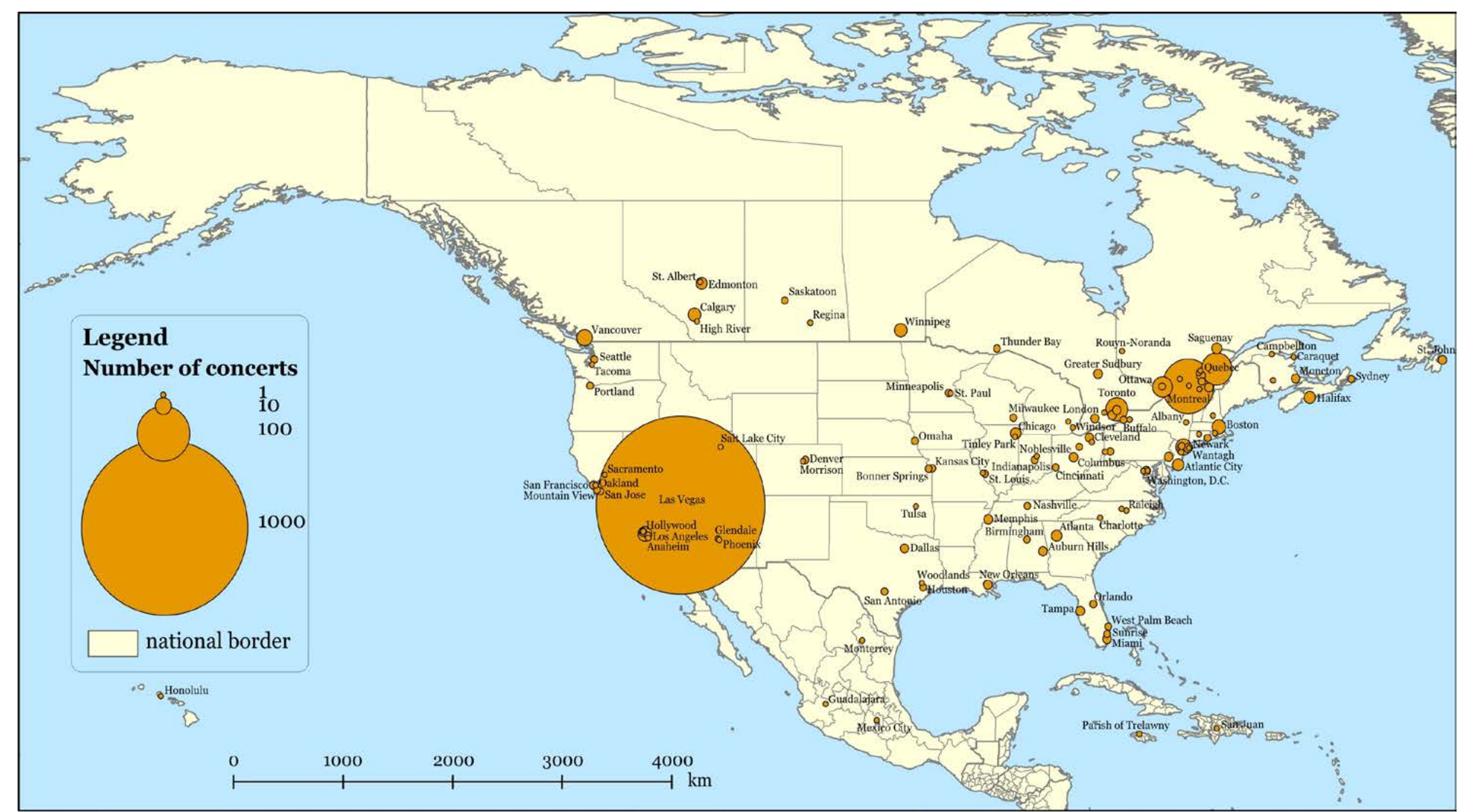

Figure 6: American cities as music scenes where Dion performed (1984 - 2016) 


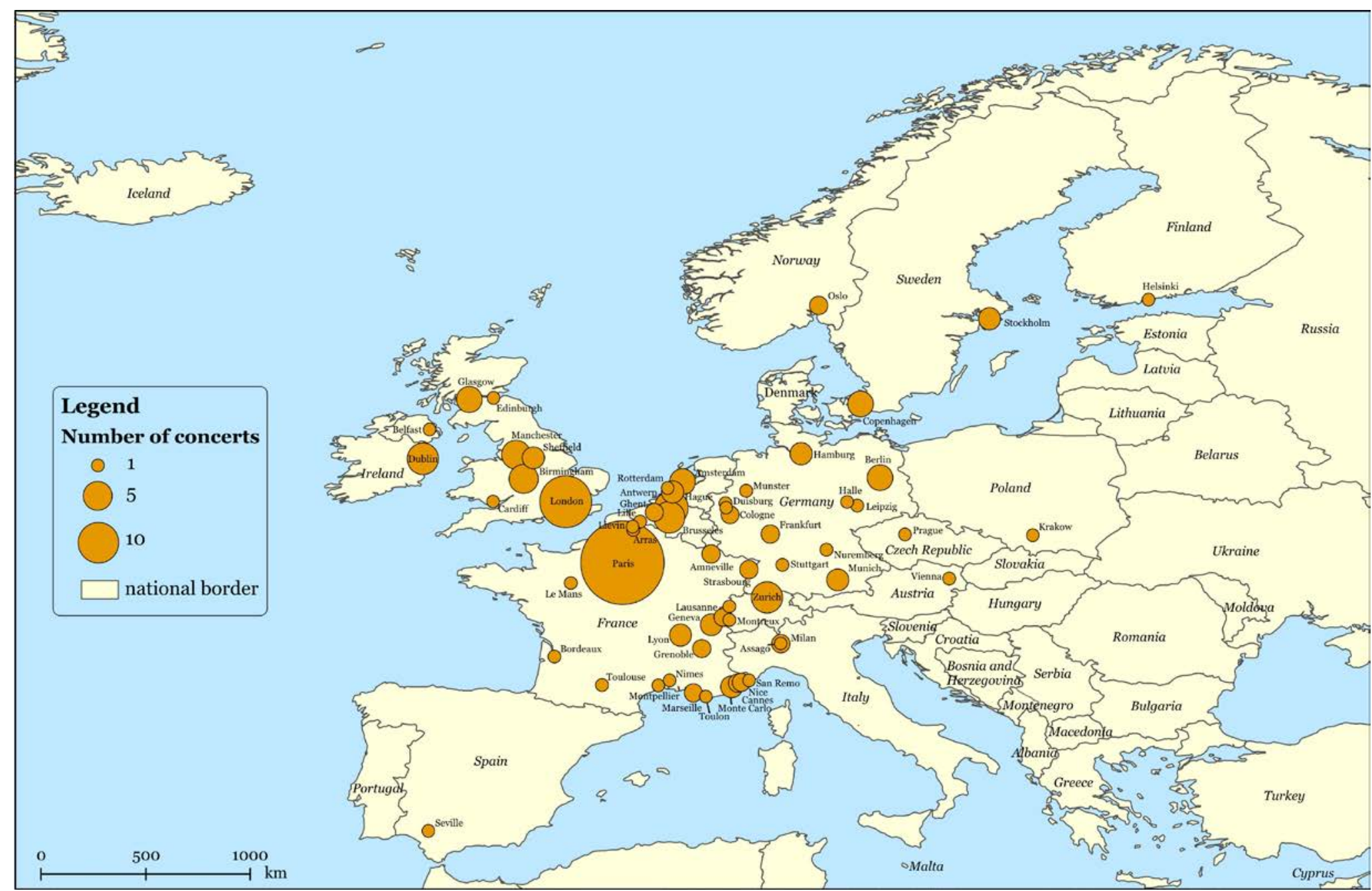

Figure 7: European cities as music scenes where Dion performed (1984 - 2016)

Source of data: Setlistfm, 2017 


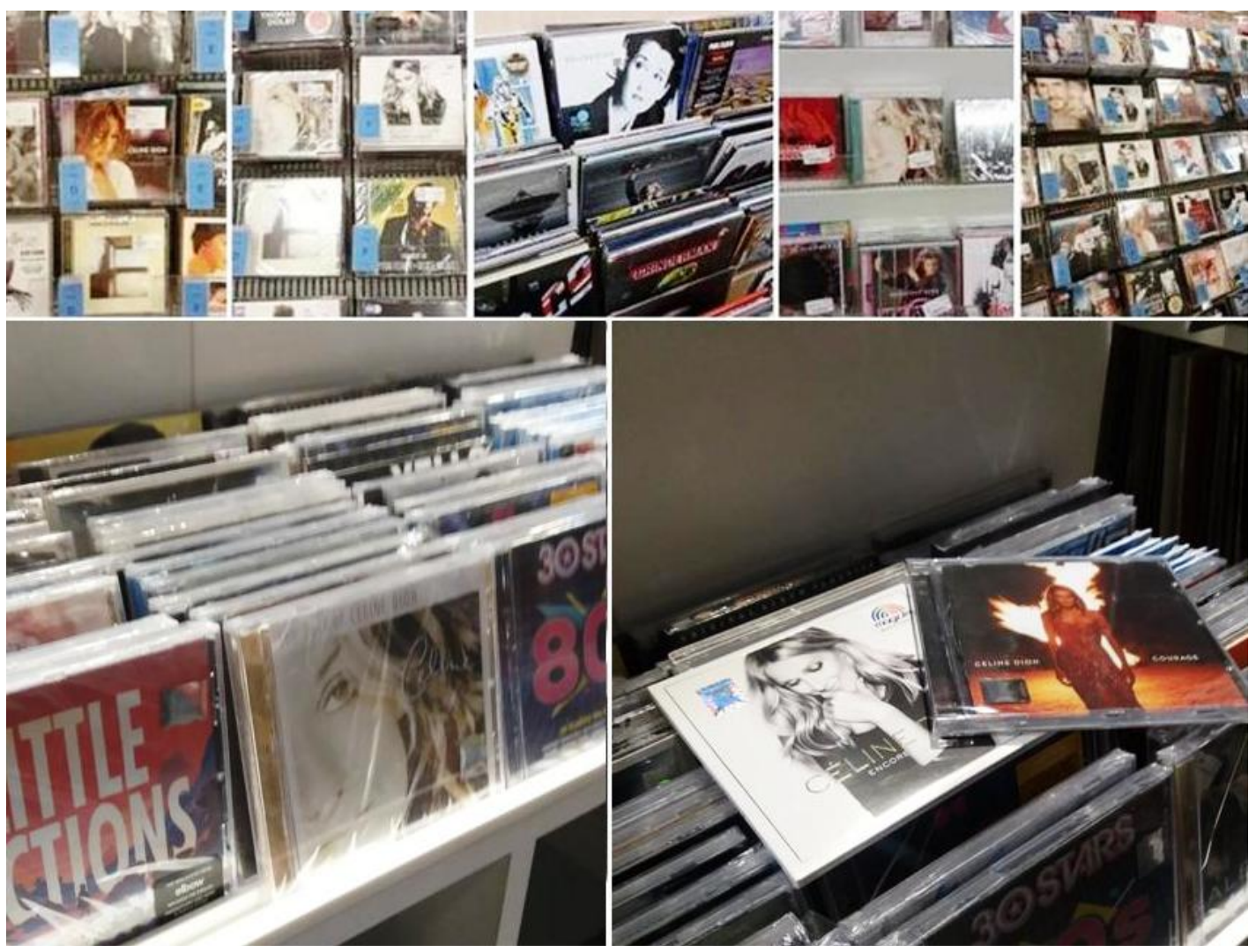

Figure 8: Dion's albums on-sale in Villach (Austria), Budapest (Hungary), Bucharest \& Braşov (Romania) (from vinyl D'Eux album, upper-middle, to Encore un soir and Courage CDs, lowerright side). Source: authors' photos $2018-2019$

Table 6: Statistics on YouTube video views with like rates and commentaries

\begin{tabular}{|l|r|r|r|}
\hline \multicolumn{1}{|c|}{ Analyzed songs } & \multicolumn{1}{c|}{ Views } & Rate of likes \% & \multicolumn{1}{c|}{ Commentaries } \\
\hline I'm alive & $176,781,871$ & 94.52 & 20,591 \\
That's the way it is & $161,879,290$ & 95.06 & 18,331 \\
A new day has come & $145,098,350$ & 94.74 & 18,279 \\
My heart will go on (official video) & $135,428,894$ & 96.29 & 39,035 \\
The power of love & $120,376,122$ & 95.48 & 17,613 \\
Pour que tu m'aimes encore & $113,876,321$ & 93.24 & 12340 \\
It's all coming back to me now & $99,493,941$ & 95.91 & 15565 \\
Ashes & $76,721,509$ & 99.99 & 51764 \\
Parler a mon père & $75,332,021$ & 94.59 & 12,931 \\
Encore un soir & $62,250,347$ & 93.26 & 11,322 \\
I drove all night & $54,200,642$ & 94.61 & 6,019 \\
Because you loved me & $43,505,789$ & 96.32 & 2,362 \\
To love you more & $21,665,607$ & 95.42 & 3,944 \\
Falling into you & $10,889,428$ & 96.20 & 1,277 \\
Where does my heart beat now & $9,554,511$ & 96.56 & 2,895 \\
Immortality & $37,327,012$ & 96.02 & 4,848 \\
Courage & $3,992,970$ & 98.18 & $\mathbf{7}, 840$ \\
Flying on my own & $3,653,081$ & 97.56 & 3,020 \\
\hline Total & $\mathbf{1 , 3 5 2 , 0 2 7 , 7 0 6}$ & - & $\mathbf{2 4 9 . 9 7 6}$ \\
\hline Medium average & $\mathbf{7 5 , 1 1 2 , 6 5 0 . 3 3}$ & $\mathbf{9 5 . 7 7}$ & $\mathbf{1 3 , 8 8 7 . 5 5}$ \\
\hline
\end{tabular}

Source: YouTube, Updated December 30, 2019 
Beyond the physical and virtual, direct or indirect audience, Dion's contribution was recognised worldwide by countless awards. In 2016, she won the Icon Award at the Billboard Music Awards. It is the highest prize that a music legend would achieve in a lifetime as recognition of the artists' involvement both in global popular music and in other community backgrounds worldwide. ${ }^{22}$ Throughout her career, she has also received numerous awards for different artistic accomplishments: artist of the year, women of the year, favourite artist, best sales, best female albums, best singer, best movie soundtracks, most successful artist, top female artist, and top selling Canadian artist. These awards have come from Canada, the US, Japan, France, Switzerland, the UK, Malta, Germany, Spain, Denmark, Greece, South Africa, Poland, Hungary, etc. Numerous worldwide prizes have also come her way including the Billboard Music Awards, World Music Awards, American Music Awards, Grammy, Felix and Juno Awards. Dion was acknowledged as the Millennium Entertainer receiving an Honorary Doctorate in Music by Laval University (Quebec) for professional achievements in music and has won two Academy Awards. In terms of cultural and political contexts, Dion was awarded The Order of Canada and The National Order of Québec as an officer for her outstanding contribution to world music, for her worldwide musical influence and for her commitments to numerous humanitarian causes. ${ }^{23}$ For her influence on the French language, she became a Knight of the French Legion of Honour and was decorated by the former president Nicolas Sarkozy in 2008 (Figure 9, left), who stated: "France thanks you because your talent and your success; you have taken our language beyond our own borders. It's extraordinary to have an artist who sings in French who takes our language to every continent." ${ }^{24}$ Considering the sense of belonging and the cultural identity in her discourse (Figure 9, right), Dion dedicated the medal to her French family since she always recognized her French-Canadian identity worldwide as a proud Quebecois. ${ }^{25}$ Her origin is the cultural heart of her music, reached to a global audience. In keeping with this, at the 1990 Adisq Gala, despite the global success of her English music, Dion refused The English Artist of the Year Award (Dion \& Germain, 2000; Young, 2001; Wilson, 2014). ${ }^{26}$

This demonstrates the sense of belonging and the place attachment of the artist. Her native language is practised in her family everyday life (see Laporte \& Snyder, 2010), and Canada is always acknowledged as the artist's home. In keeping with Dion's place attachment to her native country and her native culture, places, people and fans, in the course of her 2016 Canadian tour, the artist said deeply emotional: "I am ecstatic to be home," while related to her native audience acclamation Dion stated: "I did not expect what happened tonight" (Retrospective, 2016). These statements argue the artist's identity mirrored in her native culture also confirmed by the Medal of Arts and Letters. It was offered to the artist by France's Minister of Culture to recognize the best-selling French-language artist in history, the Quebec artist achieving the most success outside the Province of Quebec, and the most success Quebecois artist in a language other than French. The Governor General's Award was honoured with a recognition medal on Canada's $125^{\text {th }}$ Birthday for Dion's contribution to Canadian culture. As a Quebecois artist achieving the most success outside Quebec in the

${ }^{22}$ According to https://www.youtube.com/watch?v=sIJbFawCbkE, Accessed July 2017.

${ }^{23}$ See http://www.celinedion.com/about Accessed July 2017; a complete list of awards is included in this website.

${ }^{24}$ Laporte \& Snyder, 2010.

${ }^{25} \mathrm{Ibidem}$; see also Lamoureux \& Snyder, 2013; Beauregard, 2002.

${ }^{26}$ See Dion \& Germain, 2000; Beauregard, 2002. A video is available at https://www.youtube.com/watch?v=ivXa4mWebC4, Accessed July 2017. 
Francophone market, she was awarded the Trophy of Radio France International/Francophone Council of Music. Furthermore, Victoires de la Musique Award acknowledged Dion as the best Francophone artist. For the most successful Quebecois artist in a language other than French, multiple Felix Awards complete Dion's success in global music culture. ${ }^{27}$
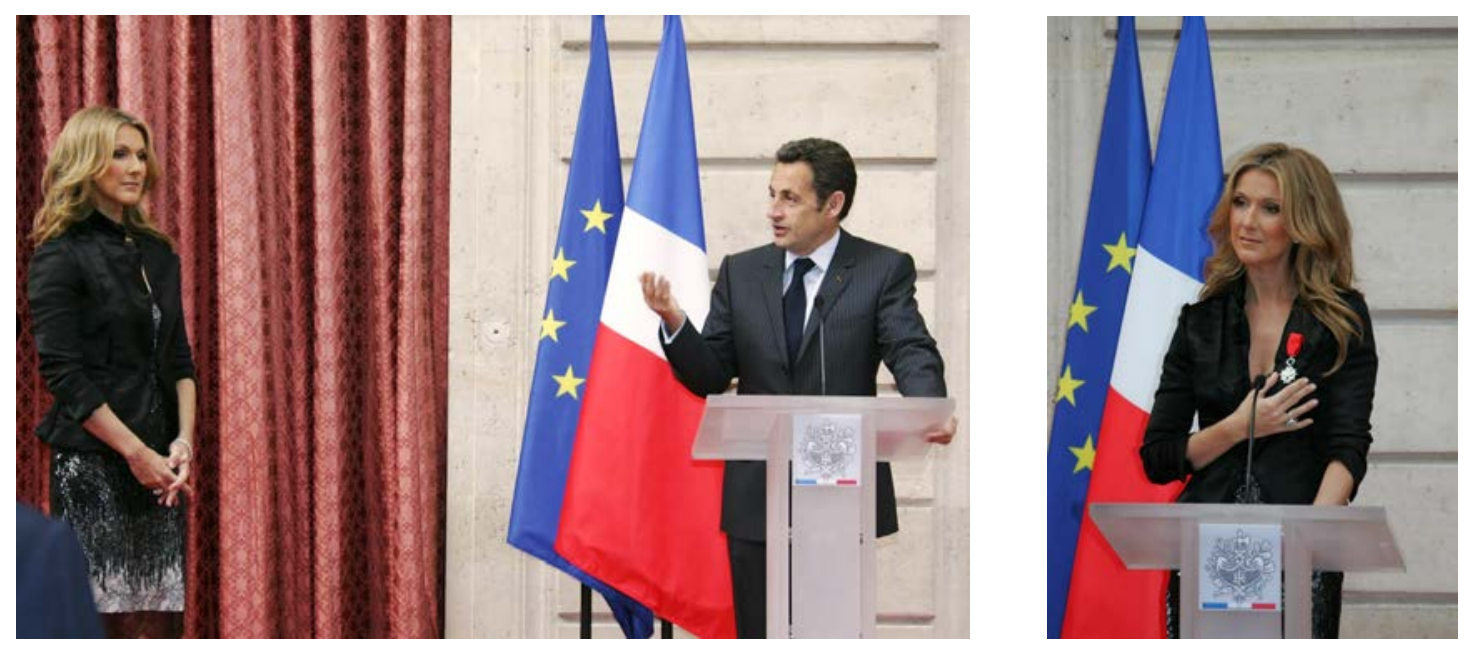

Figure 9: (left) Céline Dion receiving the Legion of Honour from France, President Nicolas Sarkozy in May, 2008. (right) Céline Dion's discourse dedicating the medal to her French-

\section{Canadian family}

Source: Gulliver Trade, Romania, a master delegate of gettyimages, 2018.

Then The Legend Award (World Music Awards) in recognition of a top recording artist in terms of global success and outstanding contribution to the music industry was awarded. The Nevada Commission on Tourism acknowledged Dion as the Entertainer of the New Millennium for contribution in the bettering of the quality of life for Nevada residents and for the immense success of the Las Vegas show, a revolution in music industry. Many awards attest the humanitarian involvement as ELLA Award (USA) for contribution to music, humanitarian and community support as the artist has always been devoted to many humanitarian causes regardless of places, identities, cultures, races, or regions. ${ }^{28}$ She supports the Foundation against Cystic Fibrosis - a fact that she has mentioned on all of her album covers. Stand up to cancer, American Red Cross, Voices that care (supporting the troops in the 1992 Gulf War), Les yeux de la faim (helping starving Ethiopians) are other humanitarian causes together with support to the victims of the terrorist attacks in New York in 2001, Paris in 2015 and recently Manchester and Las Vegas in 2017. Crossing cultures and music identities, Dion has performed together with important music legends with some of the best voices in the world, including Luciano Pavarotti, Andrea Bocelli, Barbra Streisand, Frank Sinatra, Mariah Carey, Aretha Franklin, etc.

As Dion has stated, through her music she is always thrilled to share her love with the world. Therefore, love is the major theme of her repertoire since she considers that everything in life

${ }^{27}$ See www.celinedion.com/about Accessed July 2017. The awards situation of the singer could be a new avenue for further research dealing with music, geography and the greatest rewards.

28 See Laporte \& Snyder, 2010, and Billboard at https://www.youtube.com/watch?v=xkIZ5wysniE, Accessed July 2017. 
is based upon love and she shares the love with the world (through her music and fans). ${ }^{29}$ Since her songs speak about love, miracles and power, when asked in Shanghai about China's future, Dion stated "if you follow your dreams it means you follow your heart. If you do follow your heart, I don't think you can go wrong" (see Laporte \& Snyder, 2010).

Such messages transcending music are the main reasons for which this legendary music icon is worldwide appreciated. Songs like The power of the dream, The power of love, Let's talk about love, Love can move mountains, and many others remain emblematic as love is their central theme. Lyrics analysis demonstrated this finding, revealing that Dion's outstanding contribution to global music culture stands on the message conveyed in the music that she has performed. Love, trust, life, hope, joy optimism, courage, generosity, family and the landscapes of home and native places, prays, memories, children and childhood, care for all those in need, peace, freedom and fraternity are relevant issues in Dion's music. ${ }^{30}$ Overall, true values and real virtues are expressed in her universal music touching the audience worldwide. ${ }^{31}$

The moving messages conveyed in Dion's music make people find and resonate itself with the artist's music culture arguing the universal trait of popular music that appears as a pervasive mean of global identities and communication. In summing these questions all up, the song Let's talk about love remains emblematic portraying this issue, with the singer saying that: "Everywhere I go, all the places that I've been/Every smile is a new horizon on a land I've never seen/There are people around the world - different faces different names/But there's one true emotion that reminds me we're the same.../Let's talk about love... ." This is just an example. Therefore, Dion's outstanding contribution to global culture is confirmed through musical messages expressed through a unique and moving voice, through epic live performances, concerts and worldwide tours alongside her respect and admiration for the audience, fans, people and communities. In 2016, addressing her fans, Dion stated: "My voice does not resonate without you. You have made my childhood dream come true. I hope I have inspired you to reach out for yours." 32

Behind the signs of "divafication" (see Lister, 2001), Dion's music, career and life define her as a symbol of kindness, honesty and generosity, showing in her turn, respect and admiration for fans, audience, people, cultures, communities and the world's cultural values. Through music, the artist always shares her love and supports people regardless of their age, race, nationality and other cultural identities. Certainly, beyond the music, this is the most important contribution of an iconic music legend to the global popular culture.

\section{CONCLUSIONS}

This paper has dealt with the intimate connections between music geography and iconic music legends, taking Céline Dion as a case study. Its analysis has demonstrated the spatial focus relevance for music, unveiling the rise of Dion artist as a global music legend, with an impressive contribution to global music culture. Both issues are supported by the emergence

${ }^{29}$ According to Making of Somebody love somebody. https://www.youtube.com/watch?v=MzkJf9899rs, Accessed July 2017.

30 These findings are based on the analysis of lyrics.

${ }^{31}$ See the statement in Laporte \& Snyder, 2010.

${ }^{32}$ According to https://www.youtube.com/watch?v=wWEOvnMAgvQ, Accessed July 2017. 
of popular music through globalisation and music industry alongside the music consumption by the fans and communities and by the people admiration for iconic artists. Music industry has shaped representative pathways in music production and consumption, producing a large international audience for specific singers. As has been argued, artists' domestic music has been deterritorialised, replaced and diffused to a global audience, turning them into music legends based on the audience perceptions, admiration and public demand.

From her French musical hearth of Quebec, Dion's music has spread across the world through various channels of cultural diffusion. Supported by some of the most important music companies, by family, by fans from worldwide communities and through professional management, Dion developed her career through different ways. Recordings and epic performances were the most important music products, allowing her to reach out from her domestic public to a global audience that in time produced large communities of fans worldwide. Then, in line with music consumers' demand, important sell-out concerts and tours were realised worldwide to share the music with the world, demonstrating the global distribution of Dion's music. Specific pathways were followed in line with local, regional and global features of cultural and economic backgrounds.

The passion for singing allowed Dion to share her music with people through her unique voice, songs and performances, which has been internationally acknowledged. The French-Canadian songstress spread her French musical culture to France, Paris being both the most important European music scene and the cultural hearth for Dion's music diffusion in Europe. Dion's determination to be successful in the global music markets through fair competition and always striving for excellence brought her to Dublin and Japan where she won important prizes. This demonstrates not only her spectacular reach in Europe and Asia but also worldwide, as well as her preference to connect with a large international audience, even though she only performed in French at that time.

Turning to English music (without altering her native French identity of which the artist is always so proud), Dion soon dominated the Anglophone music markets and became the most important Anglophone and Francophone artist of her day. Continuous recordings and live performances in English and French, with numerous albums released and sold by the most important global music companies, kept the singer in the top positions of the global music charts. This pathway has been ensured by the singer's professional epic performances. Since gaining her worldwide success, Dion has continuously strived for excellence in her performances and devotion to her audiences regardless of their identity, age, gender, ethnicity, and religion. Respect and admiration for her audience made the singer a generous artist who through music has diffused her unique messages of love that made communities resonate in unison with her. Regardless of different cultural traits, people and communities find themselves in the same specific cultural identity of the singer and her music, thus demonstrating the universal expression of music as a cultural global product. Through recordings, tours and epic concerts on different worldwide music scenes, Dion has broadcast the music to her fans. Even though her residency show in Las Vegas ended, it remains emblematic in the global music industry and in music tourism for allowing people to join her live performances. With every show selling out for years, these concerts demonstrate the singer's unique power of attraction for people and the music consumers' demand.

Music cartographies have revealed particular delineating regions, unveiling certain geography of inequality in spatial terms. The key territories of the hegemonic Anglophone music industry prevail. In light of this finding of spatial heterogeneity, the virtual musical environment appears more homogenous since numerous communities of fans are present online in regions 
where Dion has never performed live. Broadcast, TV and the internet are relevant channels by which her music is consumed and appreciated. Her outstanding contribution to global music culture can be seen in her gross sales, countless tours, sold-out concerts and personal recognition. Multiple acknowledgements from various awards offered by global musical forums and official national authorities are further testament to her outstanding contribution to global music culture. Dion is the only artist diffusing French and English music worldwide who has enriched the global culture of popular music in recent decades. She dominated both the Anglophone and Francophone markets for years, framing a unique cultural expression through which people find itself as part of Dion's music culture. It is argued by the music products as recordings, tours, epic concerts and sales worldwide developed and consumed by a global audience under the umbrella of its musical preferences and its cultural perception of the true values of popular music culture.

The findings of this geographical analysis testify Dion's outstanding contribution to music and to global popular music culture and it opens new fertile backgrounds for further research both on the present case study and on other legendary music icons of the world. Considering the first avenue, further research might focus on the cultural geographies of legendary artists, on their global recognition through greatest rewards and on the analysis of lyrics in different emblematic songs to understand why music of different famous artists has such a power of attraction to the wider audiences belonging to different cultural identities. Pioneering the links between music geographies and legendary music icons through this particular case study, this research opens new avenues for further research and invites for critical debates and academic dialogues on this complex and challenging topic related to geography, music and the geographical analyses of iconic music legends.

\section{Acknowledgements}

I would like to thank Dr. Andrei Dornik for his support in designing the maps for this study and to Rory O'Farrell for the work in stylistic English proofreading. I extend my acknowledgments to Gulliver Trade Romania, a master delegate of gettyimages, for photo credits and to the anonymous reviewers for their instructive feedback and valuable suggestions in improving the content of this paper. Also I am thankful to many researchers and professors for their suggestions, comments, and criticism and mostly for their support and encouragement in completing this paper as a result of an important work and devotion both for geography and music, as well as a challenging approach in dealing with music geographies. Special thanks to my family for unconditional support in this research. Any suggestion on the content of this paper in order to develop further research on this topic is welcomed and I am so grateful for this.

\section{Fair Use Disclaimer}

This paper contains copyrighted material the use of which has not always been specifically authorized by the copyright owners. I make such a material available in my effort to advance understanding of music geographies in relation to legendary music icons through a particular case study. I believe this constitutes a fair use of any such copyrighted material as provided for in section 107 of the US Copyright Law. This material is distributed without profit, and no financial gain is followed by the author. The information of this article is for research and educational purposes with students and researchers in academic field. The paper has no commercial scopes being a geographic non-profit article for teaching, scholarship and research using positive academic criticism, commenting and reporting findings and results in the field of music geographies. The article has no defamatory content. The paper aimed to present, to map and discuss in a manner of positive criticism, through a geographical analysis, the outstanding contribution to music and global popular music culture of Dion legendary iconic artist. 


\section{REFERENCES}

ANDERSON, B., MORTON, F., \& REVILL, G. (2005). Practices of Music and Sound. Social \& Cultural Geography, 6(5), 639-644. DOI: $10.1080 / 14649360500298282$

ANDERSON, B. (2004). Recorded Music and Practices of Remembering. Social \& Cultural Geography, 5(1), 3-20. https://doi.org/10.1080/1464936042000181281

ATTALI, J. (1985). Noise: The Political Economy of Music. Minneapolis, London: University of Minnesota Press.

BANKS, M., LOVATT, A., O'CONNOR, J., \& RAFFO, C. (2000). Risk and Trust in the Cultural Industries. Geoforum 31(4), 453-464.

BEAUREGARD, S. (2002). Passion Celine Dion: The Ultimate Reference for the Fan. Victoria: Trafford Publishing.

BENNETT, A. (2000). Popular Music and Youth Culture: Music, Identity and Place. London: Macmillan Press.

BENNETT, A., \& PETERSON, R.A. (eds.) (2004). Music Scenes: Local, Translocal and Virtual. Nashville: Vanderbilt University Press.

BOUVIA (2017). Céline Dion. One of the Most Powerful, Moving Voices. People Strive, June 25, 2017. Retrieved 15 December 2018, from http://www.peoplestrive.com/peoplestrive-stories-misc-qoutes/celine-dion/

BROWN, A., O'CONNOR, J., \& COHEN, S. (2000). Local Music Policies within a Global Music Industry: Cultural Quarters in Manchester and Sheffield. Geoforum 31(4), 437-451. https://doi.org/10.1016/S00167185(00)00007-5

BYKLUM, D. (1994). Geography and Music: Making the Connection. Journal of Geography, 93(6), 274-278. DOI: $10.1080 / 00221349408979833$

CARAMAN-FOteA, D., \& NicolaU, C. (1999). Dicţionar Rock, Pop, Folk [Rock, Pop, Folk Dictionary]. Bucharest: Humanitas.

CARNEY, G.O. (1974). Bluegrass Grows All Around: The Spatial Dimensions of a Country Music Style. Journal of Geography, 73(4), 34-55. DOI: 10.1080/00221347408980277

CARNEY, G.O. (1987a). The Sounds of People and Places: Readings in the Geography of American Folk and Popular Music. Boston: University Press of America.

CARNEY, G.O. (1987b). T for Texas, T for Tennessee: The Origins of American Country Music Notables. In: Carney, G. (ed.), The Sounds of People and Places (pp. 55-74). Boston: University Press of America.

CARNEY, G.O. (1990). Geography of Music: Inventory and Prospect. Journal of Cultural Geography, 10(2), 35-48. https://doi.org/10.1080/08873639009478446

CARNEY, G.O. (ed.) (1998a). Baseball, Barns, and Bluegrass: A Geography of American Folklife. Lanham: Rowman \& Littlefield.

CARNEY, G.O. (1998b). Music Geography. Journal of Cultural Geography, 18(1), 1-10. https://doi.org/10.1080/08873639809478309

CARNEY, G.O. (2003). The Sounds of People and Places: A Geography of American Music from Country to Classical and Blues to Bop. Lanham: Rowman \& Littlefield.

CAVES, R.E. (2000). Creative Industries. Contracts between Arts and Commerce. Cambridge: Harvard University Press.

CHENAIL, R.J. (2011). YouTube as a Qualitative Research Asset: Reviewing User Generated Videos as Learning Resources. The Qualitative Report, 16(1), 229-235.

COHEN, S. (1991). Popular Music and Urban Regeneration: The Music Industries of Merseyside. Cultural Studies, 5(3), 332-346. https://doi.org/10.1080/09502389100490281

COHEN, S. (1995). Sounding Out the City: Music and the Sensuous Production of Place. Transactions of the Institute of British Geographers, 20(4), 434-446.

COHEN, S. (2017). Decline, Renewal and the City in Popular Music Culture: Beyond the Beatles. London: Routledge.

CONNELL, J., \& GIBSON, C. (2003). Sound Tracks: Popular Music Identity and Place. London: Routledge. 
CONNELL, J., \& GIBSON, C. (2004). World Music: Deterritorializing Place and Identity. Progress in Human Geography, 28(3), 342-361. https://doi.org/10.1191/0309132504ph493oa

CONNELL, J., \& GIBSON, C. (2009). Ambient Australia: Music, Meditation, and Tourist Places. In: Johansson, O., \& Bell, T.L. (eds.), Sound, Society and the Geography of Popular Music (pp. 67-88). Farnham: Ashgate.

CURRID, E. (2007). The Warhol Economy. How Fashion, Art and Music Drive New York City. New York: Princeton.

DAHLGREEN, W. (2016). World's Most Admired 2016. Putin and the Queen Up, Pope Francis and Malala down, YouGov, May 7, 2016. Retrieved 12 June 2017, from https://yougov.co.uk/news/2016/05/07/wma-2016/

DION, C., \& GERMAIN, G.H. (2000). Céline Dion: Ma vie, mon rêve. Paris: Laffont.

EVERINGTON, K. (2018). 300,000 Fans Crash Ticket System for Céline Dion Concerts in Taipei, More Shows Possible. Taiwan News, January 23, 2018. Retrieved 15 February 2018, from https://www.taiwannews.com.tw/en/news/3347524

FINN, J. (2011). Introduction: On Music and Movement. Aether: The Journal of Media Geography, 7(20), 1-11.

FINN, J., \& LUKINBEAL, C. (2009). Musical Cartographies: los Ritmos de los Barrios de la Habana. In: Johansson, O., \& Bell, T.L. (eds.), Sound, Society and the Geography of Popular Music (pp. 127-144). Lanham: Ashgate.

FLORIDA, R., \& JACKSON, S. (2010). Sonic City: The Evolving Economic Geography of the Music Industry. Journal of Planning Education and Research, 29(3), 310-321. https://doi.org/10.1177/0739456X09354453

FLORIDA, R., MELLANDER, C., \& STOLARICK, K. (2010). Music Scenes to Music Clusters: The Economic Geography of Music in the US, 1970-2000. Environment and Planning A, 42(4), 785-804. https://doi.org/10.1068/a4253 http://www.tandfonline.com/doi/ref/10.1080/10350330.2012.731904?scroll=top

FORBES MAGAZINE (2017). America's Richest Female Entertainers 2017. Retrieved 18 October 2017, from https://www.forbes.com/pictures/591bdaac4bbe6f1b730a510a/3-celine-dion-400-million/\#e498d5241505

FORMAN, M. (2002). Soundtrack to a Crisis: Music, Context, Discourse. Television \& New Media, 3(2), 191-204. https://doi.org/10.1177/152747640200300211

FRASER, B.P., \& BROWN, W.J. (2002). Media, Celebrities, and Social Influence: Identification with Elvis Presley. Mass Communication \& Society, 5(2), 183-206.

FRITH, S. (2012). Editorial. Social Semiotics, Special Issue: Live Music, 22(5), 517-522. https://doi.org/10.1080/10350330.2012.731894

GALLAGHER, M., \& PRIOR, J. (2014). Sonic Geographies: Exploring Phonographic Methods. Progress in Human Geography, 38(2), 267-284. https://doi.org/10.1177/0309132513481014

GALLAGHER, M., KANNGIESER, A., \& PRIOR, J. (2017). Listening Geographies: Landscape, Affect and geotechnologies. Progress in Human Geography, 41(5), 618-637. https://doi.org/10.1177/0309132516652952

GIBSON, C., \& CONNELL, J. (2004). Bongo Fury: Tourism, Music and Cultural Economy at Byron Bay, Australia. Tijdschrift voor Economische en Sociale Geografie, 94(2), 164-187. DOI: 10.1111/1467-9663.00247

GERRA, L. (2007). Laurent Gerra vs Nicolas Sarkozy numéro 1 De retour sur le blog. Retrieved 18 June 2018, from http://goldengate2000.skyrock.com/2268940575-Laurent-Gerra-vs-Nicolas-Sarkozy-numero-1-De-retoursur-le-blog.html

GLAESER, E.L., KOLKO, J., \& SAIZ, A. (2001). Consumer City. Journal of Economic Geography, 1(1), 27-50. https://doi.org/10.1093/jeg/1.1.27

GLATZER, J. (2005). Céline Dion: For Keeps. NJ: Andrews McMeel Publishing.

GRENIER, L. (2000). Questions de renommée: les mises en mémoire du phénomène Céline Dion. Recherches féministes, 13(2), 33-45.

GRENIER, L. (2002). Global Pop on the Move: The Fame of Céline Dion Within, Outside and Across Québec. Journal of Australian Canadian Studies, 19(2), 31-48.

HOGAN, E. (2007). 'Enigmatic Territories': Geographies of Popular Music. Chimera, 22, 162-180.

HRACS, B.J., SEMAN, M., \& VIRANI, T.E. (eds.) (2016). The Production and Consumption of Music in the Digital Age. New York: Routledge. 
HUDSON, R. (2006). Regions and Place: Music, Identity and Place. Progress in Human Geography, 30(5), 626-634. https://doi.org/10.1177/0309132506070177

HUI, K.L., \& PNG, I. (2003). Piracy and the Legitimate Demand for Recorded Music. Contributions in Economic Analysis \& Policy, 2(1), 1-22. https://doi.org/10.2202/1538-0645.1160

HURLEY, E. (2011). National Performance: Representing Quebec from Expo 67 to Céline Dion. Toronto: University of Toronto Press.

JOHANSSON, O., \& BELL, T.L. (eds.) (2009). Sound, Society and the Geography of Popular Music. Lanham: Ashgate.

JONES, C. (2001). Quebec Song: Strategies in the Cultural Marketplace. Quebec Studies, 31, 50-60.

KATSILOMETES, J. (2019). Céline Dion Closes 1,141-show Residency on Las Vegas Strip, Las Vegas Review Journal, June 9. Retrieved 12 June 2019, from https://www.reviewjournal.com/entertainment/ entertainmentcolumns/kats/celine-dion-closes-1141-show-residency-on-las-vegas-strip-video-1683061/

KEARNEY, D. (2009). I Can't Believe the News Today: Music and the Politics of Change. Chimera, 24, 122-140.

KEARNEY, D. (2010). Listening for Geography: The Relationship between Music and Geography. Chimera, 25, 47-76.

KONG, L. (1995). Popular Music in Geographical Analyses. Progress in Human Geography, 19(2), 183-198. https://doi.org/10.1177/030913259501900202

KONG, L. (1999). The Invention of Heritage: Popular Music in Singapore. Asian Studies Review, 23(1), 1-25. https://doi.org/10.1080/10357829908713218

KRIMS, A. (2007). Music and Urban Geography. New York: Routledge. https://doi.org/10.4324/9780203942376

KRUSE, R.J. (2003). Imagining Strawberry Fields as a Place of Pilgrimage. Area, 35(2), 154-162. doi:10.1111/14754762.00248

KRUSE, R.J. (2004). The Geography of the Beatles: Approaching Concepts of Human Geography. Journal of Geography, (103)1, 2-7. DOI: 10.1080/00221340408978566

KRUSE, R.J. (2005). The Beatles as Place Makers: Narrated Landscapes in Liverpool, England. Journal of Cultural Geography, 22(2), 87-114. https://doi.org/10.1080/08873630509478240

KRUSE, R.J. (2009). Geographies of John and Yoko's 1969 Campaign for Peace: An Intersection of Celebrity, Space, Art, and Activism. In: Johansson, O., \& Bell, T.L. (eds.), Sound, Society and the Geography of Popular Music (pp. 11-31). Farnham: Ashgate.

KRUSE, H. (2009a). Local Independent Music Scenes and the Implications of the Internet. In: Johansson, O., \& Bell, T.L. (eds.), Sound, Society and the Geography of Popular Music (pp. 205-217). Farnham: Ashgate.

KUHLKE, O. (2009). The Geography of "Canadian Shield Rock": Locality, Nationality, and Place Imagery in the Music of the Rheostatics. In: Johansson, O., \& Bell, T.L. (eds.), Sound, Society and the Geography of Popular Music (pp. 161-184). Farnham: Ashgate.

LAPORTE, S., \& SNYDER, J. (2010). Céline. Through the Eyes of the World. Go Beyond the Music. Sony Music, Canada.

LAMOUREUX, J., LAPORTE, S., \& SNYDER, J. (2008). Céline Dion. Live in Las Vegas. A New Day. Dragone/ Productions, Sony Music, Canada.

LAMOUREUX, J., \& SNYDER, J. (2009). Céline. Tournée mondiale Taking Chances, Le Spectacle. Sony Music, Canada.

LAMOUREUX, J., \& SNYDER, J. (2010). Céline Dion. Taking Chances World Tour, The Concert. Sony Music, Canada.

LAMOUREUX, J., \& SNYDER, J. (2013). Céline. Une Seule Fois. Live 2013. Sony Music, Canada.

LASHUA, B., SPRACKLEN, K., \& LONG, P. (2014). Introduction to the Special Issue: Music and Tourism. Tourist Studies, 14(1), 3-9. https://doi.org/10.1177/1468797613511682

LESLIE, D., \& RANTISI, N. (2019). Deskilling in Cultural Industries: Corporatization, Standardization and the Erosion of Creativity at the Cirque du Soleil. Geoforum, 99, 257-266. https://doi.org/10.1016/j.geoforum.2017.09.011

LEYSHON, A., MATLESS, D., \& REVILL, G. (eds.) (1998). The Place of Music. New York: Guilford.

LEVITIN, D.J. (2006). This Is Your Brain on Music: The Science of a Human Obsession. London: Penguin. 
LIEB, K.J. (2018). Gender, Branding, and the Modern Music Industry: The Social Construction of Female Popular Music Stars. London: Routledge.

LISTER, L. (2001). Divafication: The Deification of Modern Female Pop Stars. Popular Music \& Society, 25(3-4), 1-10. https://doi.org/10.1080/03007760108591796

LLOYD, R., \& CLARK, T. (2000). The City as an Entertainment Machine. Paper presented at the Annual Meeting of the American Sociological Association. http://faui.uchicago.edu/EM3.SS.doc

LOVERING, J. (1998). The Global Music Industry: Contradictions in the Commodification of the Sublime. In: Leyshon, A., Matless, D., \& Revill, G. (eds.), The Place of Music (pp. 31-56). New York: Guilford Press.

LULL, J. (1987). Popular Music and Communication. London, New York: Sage Publications.

MARTIN, E., LOUDENBACK, T., \& PIPIA, A. (2016). The Top 20 Richest Celebrities in the World. Business Insider. Retrieved 14 December 2017, from http://www.businessinsider.com/richest-celebrities-in-the-world-20168/\#20-gloria-estefan-1

MATTHEWS, L. (2018). How Much is Celine Dion Worth? Country Living, February 8, 2018. Retrieved 25 February 2018, from http://www.countryliving.com/life/entertainment/a16760895/how-much-is-celine-dion-worth

MILBURN, K. (2017). Rethinking Music Geography through the Mainstream: A Geographical Analysis of Frank Sinatra, Music and Travel. Social \& Cultural Geography, 20(5), 1-25. https://doi.org/10.1080/14649365.2017.1375550

MONTET, T. (2017). Céline Dion: Collaborations avec Adele, MHD, tracklist... On fait le point! Retrieved 20 February 2018, from https://www.purepeople.com/article/celine-dion-collaborations-avec-adele-mhd-tracklist-onfait-le-point_a255763/1

O'MALLEY-GREENBURG, Z. (2016). The World's Highest-Paid Women in Music 2016. Forbes. Retrieved 23 December 2017, from https://www.forbes.com/sites/zackomalleygreenburg/2016/11/02/the-worlds-highest-paidwomen-in-music-2016/\#4cff1981752e, https://www.forbes.com/pictures/eeel45fhgfm/10-celine-dion-27$\mathrm{mil} / \# 430 \mathrm{~b} 8 \mathrm{ab} 75 \mathrm{ebf}$

PESSES, M.W. (2009). The City She Loves Me: The Los Angeles of the Red Hot Chili Peppers. In: Johansson, O., \& Bell, T.L. (eds.), Sound, Society and the Geography of Popular Music (pp. 145-159). Farnham: Ashgate.

REVILL, G. (2005). Vernacular Culture and the Place of Folk Music. Social \& Cultural Geography, 6(5), 693-706. DOI: 10.1080/14649360500258302

RICHARDSON, M., \& WILKIE, S. (2015). Faddists, Enthusiasts and Canadian Divas: Broadcasting Quotas and the Supply Response. Review of International Economics, 23(2), 404-424. doi:10.1111/roie.12171

ROBERTS, B. (2002). Biographical Research. Buckingham: Open University Press.

RODMAN, G.B. (2013). Elvis after Elvis: The Posthumous Career of a Living Legend. London: Routledge.

ROGERS, R. (2010). Internet Research: The Question of Method - A Keynote Address from the YouTube and the 2008 Election Cycle in the United States Conference. Journal of Information Technology \& Politics, 7(2-3), 241-260. https://doi.org/10.1080/19331681003753438

ROMIG, K. (2009). A Listener's Mental Map of California. In: Johansson, O., \& Bell, T.L. (eds.), Sound, Society and the Geography of Popular Music (pp. 107-121). Farnham: Ashgate.

ROSE, G. (2016). Visual Methodologies: An Introduction to Researching with Visual Materials. London: Sage.

ROSSETTO, T., \& ANDRIGO, A. (2018). Cities in Music Videos: Audiovisual Variations on London's Neoliberal Skyline. Urban Studies, 55(6), 1257-1273. https://doi.org/10.1177/0042098017707928

SHUKER, R. (2016). Understanding Popular Music Culture. London: Routledge.

SYNDICAT NATIONAL DE L’EDITION PHONOGRAPHIQUE (2017). Un Peu De Nous @celinedion certifié Album Or (in French). Syndicat National de l'Édition Phonographique. 4 September 2017. Retrieved 5 September 2017, from https://twitter.com/snep/status/904727772920250368

SMITH, S.J. (1997). Beyond Geography's Visible Worlds: a Cultural Politics of Music. Progress in Human Geography, 21(4), 502-529. https://doi.org/10.1191/030913297675594415 
SMITH, G.D., MOIR, Z., BRENNAN, M., RAMBARRAN, S., \& KIRKMAN, P. (eds.) (2017). The Routledge Research Companion to Popular Music Education. London: Taylor \& Francis.

SONY MUSIC (2019). Céline Dion Releases New Album Courage, https://www. sonymusic.co.uk/news/2019-1115/celine-dion-releases-new-album-courage accessed December 2019.

STOKES, M. (1997). Introduction: Ethnicity, Identity and Music. Oxford: Berg Publisher.

THROSBY, D. (2002). The Music Industry in the New Millennium: Global and Local Perspectives. Global Alliance for Cultural Diversity. UNESCO-Division of Arts and Cultural Enterprise, Paris.

TILL, R. (2010). Pop Stars and Idolatry: An Investigation of the Worship of Popular Music Icons and the Music and cult of Prince. Journal of Beliefs and Values: Studies in Religion and Education, 31(1), 69-80.

VERBOORD, M., \& NOORD, S.V. (2016). The Online Place of Popular Music: Exploring the Impact of Geography and Social Media on Pop Artists' Mainstream Media Attention. Popular Communication, 14(2), 59-72.

WARNER, D. (2019). The Best Live Shows of 2019: Staff Picks. Billboard. Retrieved 8 December 2019 from https://www.billboard.com/articles/news/concerts/8545263/best-concerts-2019-live-shows

WATERMAN, S. (2006). Geography and Music: Some Introductory Remarks. GeoJournal, 65(1), 1-2. doi:10.1007/s10708-006-7047-2

WILSON, C. (2014). Let's Talk about Love. Why Other People Have Such Bad Taste. New York: Bloomsbury.

YOUNG, D. (2001). Céline Dion, the ADISQ Controversy, and the Anglophone Press in Canada. Canadian Journal of Communication, 24(4). http://www.cjc-online.ca/index.php/journal/article/view/1124/1031

YOUNG, R. (ed.) (2002). Undercurrents: The Hidden Wiring of Modern Music. London: Bloomsbury Publishing.

\section{Internet sources}

Billboard, https://www.billboard.com/articles/columns/chart-beat/7743569/celine-dion-biggest-billboard-hot-100hits, Accessed July 2017.

Billboard, https://www.billboard.com/articles/columns/chart-beat/7743569/celine-dion-biggest-billboard-hot-100hits, Accessed July 2017.

Céline Dion official website, http://www.celinedion.com, http://www.celinedionforum.com, Accessed September 2017.

Céline Dion charts and sales, http://www.celinedioncharts.com/byalbum.htm, Accessed May 2017.

Céline Dion charts and sales, http://www.celinedioncharts.com/concerts.html, Accessed May 2017.

Céline Dion charts and sales, http://www.celinedioncharts.com/byhomevideo.html, Accessed May 2017.

Céline Dion official website, http://www.celinedionforum.com, Accessed September 2017.

Making of Somebody love somebody, https://www.youtube.com/watch?v=MzkJf9899rs, Accessed July 2017.

Retrospective 2016, https://www.youtube.com/watch?v=wWEOvnMAgvQ, Accessed July 2017.

Retrospective 2017, https://www.youtube.com/watch?v=ecU1GnV3mhM, Accessed January 2018.

Setlistfm, 2017, https://www.setlist.fm.com, Accessed May - October 2017, July 2018, May 2019.

Today Show, 2016, https://www.youtube.com/watch?v=fYJSMd2gSeA, Accessed July 2017.

Viralvagon, https://www.viralvagon.com/facebook/pages/celine-dion, Accessed July 2017.

Celine Dion Taking Chances Live X Factor, https://www.youtube.com/watch?v=8KoBHIrcSMs, Accessed July 2017.

Legends officially recognized: Neil Diamond, Stevie Wonder, Prince, etc., https://www.youtube.com/watch?v=slJbFawC, Accessed September 2016.

Celine Dion Billboard Icon Award Acceptance Speech at the Billboard Music Awards 2016, https://www.youtube.com/watch?v=cJXvDFN-pxE, Accessed July 2017.

Celine Dion - Making of A New Day Has Come Album Part 1, https://www.youtube.com/watch?v=yRsoPiKR1bY, Accessed July 2017. 
Celine Dion - 3 Boys and a New Show (Part 1 of 7) HD, https://www.youtube.com/watch?v=oLcq3W1cKyc, Accessed July 2017.

Celine Dion Billboard awards (full recording: Celine singing and receiving the "icon award", https://www.youtube.com/watch?v=slJbFawCbkE, Accessed July 2017.

Celine Dion refuses an award (with English subtitles), https://www.youtube.com/watch?v=ivXa4mWebC4, Accessed July 2017.

Celine Dion. The show must go on at Billboard Music Awards 2016,

https://www.youtube.com/watch?v=xklZ5wysniE, Accessed July 2017.

Céline Dion rétrospective/retrospective 2016, https://www.youtube.com/watch?v=wWEOvnMAgvQ Accessed July 2017.

Billboard, www.billboard.com, Accessed September 2017.

\section{Discography}

Céline Dion, 1992. Céline Dion. Columbia, Sony Music, Canada.

Céline Dion, 1993. The colour of my love. Columbia, Sony Music, Canada.

Céline Dion, 1996. Falling into you. Columbia, Sony Music, Canada.

Céline Dion, 1997. Let's talk about love. Columbia, Sony Music, Canada.

Céline Dion, 1998. S'il suffisait d'aimer. Columbia, Sony Music, Canada.

Céline Dion, 2002. A new day has come. Columbia, Sony Music, Canada.

Céline Dion, 2007. Taking chances. Sony Music, Canada.

Céline Dion, 2008. These are special times. Columbia. Sony Music, Canada.

Céline Dion, 2009. Céline. Tournée mondiale Taking Chances, Le Spectacle. Sony Music, Canada.

Céline Dion, 2011. The essential Céline Dion. Sony Music, Canada.

Céline Dion, 2013. Une seule fois. Sony Music Canada.

\section{Videography}

Lamoureux, J., \& Snyder, J. (2009). Céline. Tournée mondiale Taking Chances, Le Spectacle. Sony Music, Canada. Lamoureux, J., \& Snyder, J. (2010). Céline Dion. Taking Chances World Tour, The Concert. Sony Music, Canada. Lamoureux, J., \& Snyder, J. (2013). Céline. Une seule fois. Live 2013. Sony Music, Canada.

Lamoureux, J., Laporte, S., \& Snyder, J. (2008). Céline Dion. Live in Las Vegas. A New Day... Dragone/Productions, Sony Music, Canada.

Laporte, S., \& Snyder, J. (2010). Céline. Through the eyes of the world. Go beyond the music. Sony Music, Canada. 